\title{
Mixing and Unmixing Languages
}

Mixing and Unmixing Languages uses the politics and practices of language to understand social hierarchies and social change in a post-conflict and post-socialist context.

The book focuses on Roma in Prizren, Kosovo, where the author conducted long-term ethnographic fieldwork, using language learning as a central method. Shifts in language practices among this highly multilingual group have reflected the demise of Yugoslav socialism, the rise of ethno-nationalist politics and conflict, and the post-war reversal of power relations in Kosovo. Roma in Prizren nostalgically narrate a past of cosmopolitanism and employment in contrast to the present. Their position today is complex: while they stress their relative integration, this position is fragile in the face of nationalist politics and imported neoliberal economic policies. Within this context, Roma NGO workers have found an economic niche working on projects to protect multiculturalism and minorities, funded by international aid agencies, centred on Romani language. This book discusses the historical trajectory and current configurations of a Romani organisation in the town, the standardisation of Romani and the hierarchical organisation of linguistic forms and language learning, the self-representation of Roma and the 'gypsy' image through Romani-language drama, and attitudes to purism, mixing and cosmopolitanism.

Mixing and Unmixing Languages is suitable for academics and students in the areas of linguistic anthropology and linguistic ethnography, Romani studies, South-East European studies and sociolinguistics.

Amelia Abercrombie has recently worked as a postdoctoral research associate looking at language learning among marginalised migrants in Manchester, UK. She completed a PhD in the department of Social Anthropology at the University of Manchester, UK, in 2017. Before that she was at University College London, School of Slavonic and East European Studies, UK, completing MRes East European Studies in 2011, and BA Serbian and Croatian Studies in 2008. She has also worked as a support worker for mental health and learning disabilities. 


\section{Routledge Studies in Language and Identity Series Editor: Reem Bassiouney}

The Routledge Studies in Language and Identity (RSLI) series aims to examine the intricate relation between language and identity from different perspectives. The series straddles fields such as sociolinguistics, discourse analysis, applied linguistics, historical linguistics and linguistic anthropology. It aims to study identity and language by utilizing novel methods of analysis as well as ground-breaking theoretical approaches.

Titles in Series:

Arabic in Israel

Language, Identity and Conflict

Muhammad Amara

Identity and Dialect Performance

A Study of Communities and Dialects

Edited by Reem Bassiouney

Arabic Translation Across Discourses

Edited by Said Faiq

Language, Identity, and Syrian Political Activism on Social Media

Francesco L. Sinatora

\section{Mixing and Unmixing Languages}

Romani Multilingualism in Kosovo

Amelia Abercrombie

For more titles, please visit www.routledge.com/languages/series/RSLI 


\title{
Mixing and Unmixing Languages \\ Romani Multilingualism in Kosovo
}

\author{
Amelia Abercrombie
}


First published 2021

by Routledge

2 Park Square, Milton Park, Abingdon, Oxon OX14 4RN

and by Routledge

52 Vanderbilt Avenue, New York, NY 10017

Routledge is an imprint of the Taylor \& Francis Group, an informa business

(C) 2021 Amelia Abercrombie

The right of Amelia Abercrombie to be identified as author of this work has been asserted by her in accordance with sections 77 and 78 of the Copyright, Designs and Patents Act 1988.

All rights reserved. No part of this book may be reprinted or reproduced or utilised in any form or by any electronic, mechanical, or other means, now known or hereafter invented, including photocopying and recording, or in any information storage or retrieval system, without permission in writing from the publishers.

Trademark notice: Product or corporate names may be trademarks or registered trademarks, and are used only for identification and explanation without intent to infringe.

British Library Cataloguing-in-Publication Data A catalogue record for this book is available from the British Library

Library of Congress Cataloging-in-Publication Data A catalog record has been requested for this book

ISBN: 9780367860578 (hbk)

ISBN: 9781003016694 (ebk)

Typeset in Times New Roman

by Deanta Global Publishing Services, Chennai, India 


\section{Contents}

Note on orthographies vi vili

Acknowledgements viii

Introduction $\quad 1$

PART 1

Roma, Prizren and language 17

1 Terzimahalla, Durmish Aslano and me 19

2 Durmish Aslano in Prizren: From partisan to NGO 33

3 Intangible culture and tangible employment after socialism 54

\section{PART 2}

$\begin{array}{ll}\text { Purity, mixture and representation } & 73\end{array}$

$4 O$ Romano Teatro and gypsy theatricality 75

5 Standardisation: Learning linguistics in the bath 95

6 Before the war: A nostalgic speech genre 114

Conclusion: Between two fires? Dissonance, diglossia, disorientation 133

Bibliography 145

Index 163 


\section{Note on orthographies}

Throughout this book I have kept examples of writing as close to their originals as possible, and used local orthographies for transcriptions. I use Ro to denote Romani, specifying further if there is a distinction between variants, $S h q$ to denote Albanian, $B C S$ to denote Bosnian/Croatian/Serbian and $T u$ to denote Turkish.

While Cyrillic alphabet is rarely used in Prizren, the Bosnian/Croatian/Serbian Latin orthography, the standard (Tosk-based) Albanian orthography, Turkish orthography and the local Romani orthography are all used. They are often mixed, and words are often spelt according to local pronunciations rather than standard forms. The following table is a list of orthographical differences between the languages.

\begin{tabular}{lllll}
\hline Romani & Albanian & $\begin{array}{l}\text { Bosnian/Croatian/ } \\
\text { Serbian }\end{array}$ & Turkish & IPA \\
\hline$<\mathrm{l}>*$ & $<\mathrm{ll}>$ & $<\mathrm{l}>$ & $<\mathrm{l}>$ & $/ \mathrm{f} /$ \\
& $<\mathrm{l}>$ & $<\mathrm{j}>$ & & $/ \mathrm{K} /$ \\
$<\mathrm{j}>$ & $<\mathrm{xh}>* *$ & $<\mathrm{d} z \check{*}>*$ & $<\mathrm{c}>$ & $/ \mathrm{d} /$ \\
& $<\mathrm{gj}>$ & $<\mathrm{d}>$ & & $/ \mathrm{d} /$ \\
$<\mathrm{q}>$ & $<\mathrm{q}>* *$ & $<\mathrm{c}>* *$ & $<\mathrm{c}>$ & $/ \mathrm{t} 6 /$ \\
& $<\mathrm{c}>$ & $<\mathrm{c}>$ & & $/ \mathrm{t} /$ \\
$<\mathrm{y}>$ & $<\mathrm{j}>$ & $<\mathrm{j}>$ & $<\mathrm{y}>$ & $/ \mathrm{j} /$ \\
$<\mathrm{sh}>$ & $<\mathrm{sh}>$ & $<\breve{\mathrm{s}}>$ & $<\mathrm{s}>$ & $/ \mathrm{g} /$ \\
$/ * * *$ & $<\mathrm{y}>$ & $/$ & $<$ & $/ \mathrm{u} /$ \\
$/ * * *$ & $<\ddot{\mathrm{e}}>$ & $/$ & $<\mathrm{l}>$ & $/ \mathrm{d} /$ \\
\hline
\end{tabular}

* $\quad / \mathfrak{t} /$ and $/ \mathrm{K} /$ are differentiated in Romani speech but not in this orthography.

** These graphemes represent phonemes which are distinct in the standard variants (and as such in orthographies), but not in the local variants. Many people therefore mix them up.

*** This sound is present in Romani, but is not included in this orthography.

Romani has additional aspirated consonants which are written: $<\mathrm{th}>,<\mathrm{ph}>,<\mathrm{qh}>$ and $<\mathrm{kh}>$.

These orthographies are often mixed spontaneously, which can be especially problematic with names, as people often write their name in several different 
ways. For example Durmish Aslano (Romani) could also be written Durmish Asllano (Albanian), Durmiš Aslano (Bosnian/Croatian/Serbian) or Durmiş Aslano (Turkish). This is further complicated by the fact that Albanian surnames take a definite article, so change again. For example, the Albanian surname Kryezi would have a definite nominative ending $-u$ making it Kryeziu. While in the Kingdom of Yugoslavia there was a trend to translate Albanian names into Serbo-Croat (Kryeziu, meaning 'black head' became Crnoglavić), in Socialist Yugoslavia it was more common to write Albanian names without the article, and with the Serbo-Croat orthography, giving Kruezi. To avoid taking a stance on what is essentially a political debate, I have kept people's names in the form that they would normally use, regardless of their ethnicity and the origin of their surname. 


\section{Acknowledgements}

Research for this book was carried out with ESRC funding via the North West Doctoral Training Centre, Language-Based Area Studies pathway. The book was completed as part of the AHRC OWRI (Open World Research Initiative) project.

I would like to thank both my $\mathrm{PhD}$ supervisors for their constant and very different types of support: Stef Jansen has been a source of inspiration, giving invaluable insights on anthropology, south-eastern European studies, writing and general survival, and Yaron Matras has provided rigorous feedback and inputs, drawing on his depth of knowledge on Romani studies and linguistics, and has included me in other events and opportunities. I am also grateful to my examiners, Tanja Petrović and Soumhya Venkatesan for their thorough feedback and constructive input.

I would like to thank everyone who supported me and helped me learn Romani in the field. First, to those who are no longer with us: Nexhip, who orchestrated my stay despite everything, as well as Kujtim and Ibrahim. Inshallah ano xheneti. Also: Fatmira and family for giving me a home; Enver and Drita for their kind welcome; Saverd and Moni for providing a friendly working environment; and Vera for being a true friend when I needed one most as well as an excellent cook. Edis, Erxhan and Denis, thank you for always being friendly and supportive, and for always having time to help me. More generally I would like to thank Roma in Prizren for showing me another way of living. Ov saste savorenge: tumen siklilen mange thay o yaver qhib, thay o yaver jivdipe ano tumaro diz. But kamlipe thay sastipe tumenge. I would also like to thank Saara for always providing a haven in Prishtina and Misha for unfailingly providing a warm welcome in Skopje.

Thanks also to the many people who have helped me learn languages over the years, in particular Jelena at SSEES for teaching me Serbian, and Milena and Ivan for making me speak it, Ahmet at the Yunus Emre centre for teaching me Turkish, Hasan and Mirkena for Albanian classes. I am also grateful to Danial Abondolo and Ger Duijzings for encouraging me to undertake a $\mathrm{PhD}$.

I have received useful feedback from a variety of seminars and conferences. I would particularly like to thank Gëzim Krasniqi for inviting me to take part in the South-East European Studies seminar series at SSEES, UCL, UK; Kimmo Granqvist for inviting me to take part in the Centre for Baltic and East European Studies seminar series at Södertörn University, Sweden; the organisers of the 
'The Politics of Teaching and Learning Languages' conference at SSEES, UCL, UK; the organisers and participants of the 'Romani Linguistics' conference at Södertörn University, Sweden; and Frances Pine for her feedback on the 'Postsocialism and anthropology: theoretical legacies and European futures' panel at EASA in Milan, Italy. I would also like to thank Madeleine Reeves for comments and suggestions on my early drafts, and my fellow $\mathrm{PhD}$ students at Manchester for academic and moral support. Thanks also to the anonymous reviewers for their fresh perspective and helpful suggestions in making the thesis into a book, and to my colleagues at Multilingual Manchester for their input, but more so for their kindness and humour in this period.

I would like to thank my family for awakening and never questioning my interest in this part of the world, and Perry for providing ample distractions while I was completing the book. And last but not least William for his insights, patience and his constant support. 


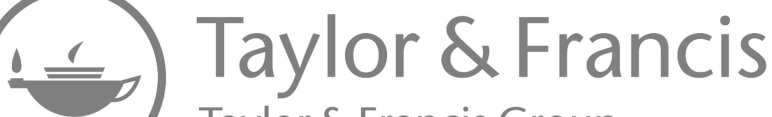

Taylor \& Francis Group

http://taylorandfrancis.com 


\section{Introduction}

\section{Preamble}

Prizren is an Ottoman-style city built along a river, with a fortress on the hillside, winding streets and Turkish-style houses. There are many mosques, a sufi Tekke, Orthodox churches and a Catholic cathedral. It is also the second-largest urban centre in Kosovo, after the capital Prishtina. According to the OSCE (2015), the population of the Prizren municipality is 177,781 , including $82 \%$ Albanian, and only $0.1 \%$ Serb, with larger minorities of Bosniacs, Turks, Gorans, Roma, Ashkali and Egyptians. Albanian and Serbian are currently the official languages of Kosovo, while Albanian, Bosnian and Turkish are official in the Prizren municipality. There is also a substantial number of international aid workers, and English, German and Italian are spoken as second languages.

The ethnic composition of Prizren is a legacy of a long-lasting Ottoman, and more recent Yugoslav, past. In Yugoslav times, Kosovo had varying levels of autonomy, though it was always part of the Republic of Serbia. During the eighties it came under military rule and its autonomy was revoked, leading in the nineties to the establishment of an Albanian parallel state and the Kosovo Liberation Army (KLA), both supported financially by the large Albanian diaspora. In 1999, following a campaign of ethnic cleansing against Albanians, vast numbers fled (to return after three months), and NATO intervened against Yugoslavia. This was followed by the KLA victory, and Serbs fled to Serb enclaves and 'inner' Serbia, the part of Serbia outside of Kosovo. From then until the declaration of independence in 2008, it was under the protection of the United Nations Mission in Kosovo (UNMIK). However, Kosovo's independence is still not recognised by many states (Serbia still claims the territory), and there is a continued foreign civil and military presence.

At the 2011 census, the population of Kosovo was estimated at $92.9 \%$ Albanian, $1.5 \%$ Serb and 5.6\% other (ASK 2015). The figure for Serbs is likely to be significantly higher, as many boycotted the census. The 'other' ethnic groups include Turks, Gorans, Bosniacs, Croats, Roma, Ashkali and Egyptians. The postwar spatial segregation of ethnic groups persists, and Serbs live almost entirely in the north, and in Serb enclaves. In this respect, Prizren is no different, and very few of the pre-war Serb population of 10,000 remain. Prizren is unusual 


\section{Introduction}

in remaining ethnically, and linguistically, mixed. Within the well-known narratives of Serbs versus Albanians, the other ethnic groups in Kosovo receive less attention, often being labelled as 'other,' or as 'communities.' In Prizren itself, however, many are keen to stress the cosmopolitan, multilingual composition of the town. It was less damaged by the war than some other parts of Kosovo, though many Albanians fled in 1998-1999, and other groups fled in 1999 and 2004, when Potkalaja (the Serbian quarter) and many of the Serbian churches were set on fire. Roma, suspected of collaborating with Serbs, fled either to Internally Displaced People's camps or abroad, though many also remained, or have since returned. There has also been an influx of Albanians from deprived rural areas, and parts of Kosovo which were more heavily affected by the conflict.

Prizrenites portray their city as cosmopolitan and harmonious, which is symbolised by the continued use of several languages from Ottoman times to the present. The cosmopolitan element of Prizrenite identity allows for long-term Roma residents, present since Ottoman times, to feel integrated into the town, while also belonging to the wider sphere of the Romani nation. However, narratives of multiculturalism and integration are punctured by the everyday experiences of this group in post-conflict, independent Kosovo.

The perspective which posits the Roma of Prizren as part of a wider Romani nation, while also a composite nation of Prizren's cosmopolitanism, sees language as both an objective characteristic and an innate possession of the ethnic group. Here language becomes more than communication: it becomes symbolic, as part of a wider Romani movement. Synchronic distinctions between Roma and non-Roma require the work of activists to embed them in the narrative of Indian origins (Gay y Blasco 2008). In this introduction I elaborate the constellations of ethnicities in Prizren and the wider region, before locating the position of Roma within them.

\section{We speak four languages: malleable identities and porous borders}

'Ja znam ciganski, srpski, šiptarski i turski' ('I know gypsy, Serbian, Albanian [derog.] and Turkish'), an elderly Roma man told me in BCS (Bosnian/Croatian/ Serbian). ${ }^{1}$ People were proud of their ability to speak several languages, and often enumerated them to show how cosmopolitan they were as Prizrenites, and how integrated they were as Roma.

'Romski, a ne ciganski' (BCS: 'Romani, not gypsy')2, corrected my host, Nexhip, who was showing me around the Romani quarter, Terzimahalla, for the first time.

I had contacted Nexhip as he was the director of the NGO Durmish Aslano. I originally tried to contact him in English, as I was unsure about using Serbian in an Albanian area of Kosovo, ${ }^{3}$ and my Albanian was limited. Nexhip told me that he didn't know much English, but once he realised I spoke BCS he was relieved that we could communicate, and told me that he spoke romski, bosanski, albanski i turski (BCS: 'Romani, Bosnian, Albanian and Turkish'). This referred to the 
same four languages as the elderly man above, but with all except Turkish being called something different.

The elderly man used the word ciganski, seemingly unaware that many deem it derogatory. Nexhip's correction alluded to a pride in Romani language and culture, which he wanted to put on a par with the other languages. While the shift away from derogatory terms for Romani has been going on for some time, in Kosovo it has recently become more widespread owing to the growth of westernfunded, multiculturalist NGOs. The shift in allegiances and ethnic identification processes has also played a part in the shift in language names shown above, and in Romani the new labels are often seen as 'standard' terms. As such, they form part of a move to standardise Romani in Prizren, as will be discussed in Chapter 5. In Romani, while gajikani, korohani, and gaunani (Ro) are used in informal speech to refer to 'BCS,' 'Turkish' and 'Albanian' respectively, boshnyakuni/ srbyuni, turkyuni and albanyuni are used in formal settings where the standard is required. However, this Romani standard is local to Prizren. Despite various attempts to institute one, there is no centralised Romani standard. Romani cultural organisations have been active in eastern Europe for the past hundred years, and an inter-state national movement has been growing since the seventies. While discrimination against Roma in much of eastern Europe has increased in the postsocialist era, there is also now a wealth of NGOs and other organisations working with Roma. Their funders have sought to valorise and celebrate Romani language and culture, and this move is linked to the use of 'Romani' (and its translations in other languages) as a neutral term. In calling his language ciganski, the old man was clearly not up to date with this shift.

The old man had also used šiptarski, which is a derogatory term for 'Albanian.' Nexhip avoided this, using albanski, the neutral term for the language of the majority nation. The use of šiptar and šiptarski in BCS refer to 'Albanians' and 'Albanian language' respectively. Despite coming from the Albanian shqiptar, a neutral term for 'Albanian,' the BCS usage is offensive, and often associated with Serb nationalist repression and violence. These terms are thus rarely used in Albanian areas, but remain common in Serb areas. This elderly man probably used the offensive term out of habit, not quite aware that such attitudes are no longer acceptable in the area.

There is a similar use of parallel terms gaunani and albanyuni to refer to Albanian language in Romani, with albanyuni being the formal, neutral variant. Gaunani etymologically refers to the language spoken in the villages, which would historically have been Albanian. This term may also carry negative connotations of being rural, backward, especially given the lower socio-economic status of many Albanians prior to the war, the ethnic distinction being inseparable from socio-economic ones.

The old man, having lived his whole life in Prizren, spent the majority of his life in Serbia. As such he said he spoke 'Serbian,' rather than 'Bosnian' or 'Croatian.' The exodus of Serbs after the war, and the de facto rejection of Serbian language by the current authorities, led Nexhip to use the more acceptable bosanski. In Prizren (and elsewhere), there has been a shift away from calling BCS 
'Serbian,' or indeed 'Serbo-Croat.' Srpski is still sometimes used in informal contexts, but the vast majority of the time, in public, it is referred to as bosanski or bošnjački. The distinction between bosanski, relating geographically to Bosnia, and bošnjački, relating to the Bosniac ethnic group, is irrelevant in the context of Prizren, and both are taken as referring to the Bosniacs ${ }^{4}$ in the Prizren municipality. While in many Albanian parts of Kosovo, BCS is not spoken at all, and even considered unacceptable, in Prizren its use is legitimised by relabelling it and detaching it from its link to ethnic Serbs.

This usage is paralleled in Albanian. In formal settings, BCS is often referred to as jugosllovenisht, boshnjakisht, kroatisht. Jugosllovenisht ('Yugoslavian') acts as a catch-all, avoiding any suggestion about the ethnicity of the speaker (though clearly distinguishing Slavs from Albanians), while boshnjakisht ('Bosniac') and kroatisht ('Croatian') are more clearly used to avoid accusing someone of being a Serb. As there are no Croats in the area, kroatisht is used solely to avoid linking BCS with Serbs, while boshnjakisht refers to the fact that the vast majority of people speaking BCS in Prizren are ethnic Bosniacs. Before the war, serbisht would have been common, and many people continue to call it this in informal settings, especially when telling people mos fol serbisht (Shq: 'don't speak Serbian'). A more offensive term, shka, is also used in Albanian to talk about Serbs and BCS.

For me, as a BCS-speaking foreigner, the choice of language was tricky to navigate: I didn't want to offend people I didn't know by speaking BCS, but equally my Albanian was limited. I tried to circumvent this issue by saying boshnjakisht (Shq: 'Bosniac'), but I generally found most people in Prizren were open to talking to me in BCS under any name, and most people preferred this either to me struggling in Albanian, or to them struggling in English.

The shift in the use of labels for languages in both Albanian and BCS since the war thus stems from political transformations. Terms that may have been neutral (or at least more widely accepted) before the war have come to be offensive, and mostly used in private, or by older people that history has passed by. Here the names used for languages are symbolic in the sense that they represent ethnic groups, groups which have been subject to change. This seemingly minor difference in the way Nexhip and the old man described their languages thus speaks volumes about the political and social changes in Kosovo since the war.

Along with language names, linguistic repertoires have also changed, not just in the aftermath of the war, but throughout living memory. Later in my fieldwork, my Romani-speaking participants told me: 'I went to school in Serbian. My father in Turkish. And now my children go in Albanian. ${ }^{5}$ People also pointed out to me that there were a variety of dialects of Romani in Prizren, as the different Romani areas had different contact languages. Despite initiatives to teach Romani in schools (from the seventies up to the present), Romani has remained primarily a private language, and Roma have studied in the surrounding languages. Language of education relates to shifting state structures, and variation in the imperative to learn a particular language at a particular time, hence these generational shifts. People also regularly contrasted life 'under the Serbs' with life 'under the Albanians,' paralleling the shift in language use. Here too, large-scale historical transformations are inextricably linked to language politics. 
In other parts of Kosovo that were previously mixed, now only Albanian or BCS are spoken. The ongoing linguistic mixture in Prizren relates to its ethnic make-up and the relative lack of violence. Romani is spoken mainly in Terzimahalla, and among groups of Roma in other parts of town, and borrows heavily from other languages. Albanian is now the closest to a default language, and is commonly used for official purposes. Turkish is spoken in the streets, shops and cafes, and is deemed symbolic of being a true Prizrenite. BCS is less spoken, but can still be heard in the streets. There is also generational variation: young Roma rarely learn BCS, unlike their parents, for whom it was a necessary language for interaction with institutions and Serbs. As we shall see, Turkish was promoted by the state after the Second World War but has since declined, though not so dramatically as BCS. Albanian is now the state language, and many Roma children are brought up as monolingual Albanian speakers.

I wanted to work with Roma as they generally spoke the most languages in the town. This was particularly true of the older generations. Within this broader context, my intention in going to Prizren was to focus not on ethnicity and conflict, but on people speaking four languages: Romani, Turkish, BCS (Bosnian/ Croatian/Serbian) and Albanian. I hoped to investigate how languages are mixed and 'unmixed' in a situation of societal multilingualism. Duijzings (2003) uses the term 'unmixing' to describe the way ethnic groups were reconstituted in postwar Bosnia. My aim was to understand how language boundaries are made and crossed, and how people's understanding of languages as distinct entities related to ethnic groups affects their speech practices. Ethnicity and language are often seen to be unproblematically linked in the region, and thus language politics is as contested as ethnicity. However, there is a clear discrepancy between the essentialised, ethnicised language ideologies used by politicians, and actual language use. Prizren is linguistically unusual: although it is an Albanian majority area, BCS is still fairly widely spoken. Turkish is widely spoken both by Turks and others, and Romani is spoken by the Roma population. Some of the traditional mahallas (monoethnic neighbourhoods or quarters) have remained, including Terzimahalla, the Romani quarter near the centre.

Despite defining my fieldsite with regard to a specific ethnic group, I want to move away from the study of ethnicity, identity formation and ethnic conflict, and to problematise the link between language and ethnicity. Rather than seeing Romani as the language of the Roma, Turkish of the Turks, and so on, I want to see how Roma use and value these languages. This discussion of language names and shifting linguistic repertoires shows that my idea of wanting to research people who speak four languages was more complex than it first appeared. But it also opens avenues of enquiry about the relationship between language and social and political change.

\section{Multiethnic Prizren}

Most days I walked to the NGO Durmish Aslano, where I volunteered during my fieldwork. It was situated just outside the city centre, and housed Radio Romano Avazo, the Romani-language radio station run by the NGO. I walked through the 


\section{Introduction}

winding streets, passing the Serbian Orthodox church Crkva Bogorodica Ljeviška (Our Lady of Ljevish). This church had been set on fire in 2004, but most of the outer structure has remained. ${ }^{6}$ It was surrounded by barbed wire, and when I approached it, I could see the blackened remains of the frescoes inside. Opposite, in front of the Ottoman clock tower, stood a police checkpoint. There were occasionally workmen doing something inside, but unlike other destroyed churches in central Prizren, there was very little visible improvement here during my stay. I did however find its name on tourist posters dotted around the city, which proudly displayed the multicultural heritage of Prizren - but these posters did not mention that the churches had been destroyed precisely because they were symbolic of a non-Albanian heritage. Some of the tourist posters were defaced.

No one I met used the church's BCS name, but referred to the church as Xhuma Xhami, meaning 'Friday Mosque.' Unusually for Prizren, a town with tens of mosques, there were no mosques nearby. When I asked people how it got its name, they told me that it wasn't really Serbian, and had previously been a mosque, but they didn't know the details.

There are many stories of mosques turning into churches and vice versa in the region. Indeed, the Sinan Pasha Mosque, the largest in Prizren, is rumoured to have been built with stones from the nearby Monastery of the Holy Archangels. Xhuma Xhami pre-dates the arrival of the Ottomans, and most likely was then turned into a mosque, before being turned back to a church again, explaining where it got its name. This history means that, while it is currently protected as an object of the Serbian Orthodox Church, many claim that it was originally Muslim, or originally Albanian. Some complain that the laws on the protection of Serbian heritage further divide what they see as Kosovo's heritage into Serb and Albanian, and that Albanians should be allowed to enter protected Serbian Churches. ${ }^{7}$

Debates over originality and ownership are part of a broader preoccupation in Balkan historiographies with 'who was there first,' which assume that proof of 'being there first' gives legitimacy to being there now, and hence the exclusion of others as newcomers. ${ }^{8}$ These narratives gain strength and support not on account of their historical accuracies, but their ability to mobilise in the present (Verdery 1991; Esbenshade 1995; Niedermüller 1998; Brunnbauer 2004). In the case of Xhuma Xhami, an essentialist notion of national groups has been anachronistically grafted onto the past to explain the unusual name of this partially destroyed church. Nowadays, people see Serbs as Orthodox, and Albanians as Muslim. The name Xhuma Xhami is therefore assumed to show that the church is really Muslim, and therefore really Albanian. As a scattered and relatively powerless group, Roma tend to be less involved in claims of being the first in the Balkans, but such claims still exist. For example, Acković (2009) emphasises the early arrival of Roma in Belgrade, even suggesting the term Singidunum (a Celtic name for the settlement that became Belgrade) may come from the word Sinti. ${ }^{9}$

These conflicting projections of history, used to construct and contest contemporary identities, are far from unusual. Duijzings (1995) discusses the complexity of ethnic affiliations and contestations among Kosovo's Croat population: Croats 
claimed that Muslim Albanians are really Croat Catholics who were Islamicised and Albanianised in Ottoman times, while Serbs claimed the Croats were Catholic Serbs, and native Croats in the Slavonian villages where the Kosovo Croat fled as refugees referred to them using the derogatory šiptari (BCS: 'Albanians') (Duijzings 1995). This shows not only that their identities shift, but also that such shifts can be interpreted as inauthenticity, and used by one group to deny the identity of another (Petrović 2008).

This contestation of, and slippage between, ethnic and religious categories is also reflected in the names of languages and ethnic groups. The elderly Roma man cited earlier used different names from Nexhip for all languages except Turkish. Turkish has kept its name in both Albanian (turqisht) and BCS (turski). It is an exception, perhaps because it is the most neutral language in the town, and is less tied to its ethnic 'owner,' being spoken as a first language by some Bosniacs, Roma and Albanians, as well as ethnic Turks, and seen as a distinguishing feature of a true Prizrenite. In Romani, there is a distinction between korohani and turkyuni again, but this seems far less politicised than terms for Serbs and Albanians. Korohani refers to the fact that Turks are seen as Muslims. ${ }^{10}$ The conflation of Turk and Muslim is common in the Balkans, but in Prizren 'Turk' is not a negative term as it is, for example, when used by Serbian and Croatian nationalists in Bosnia.

The overlap between religious and ethnic identification is a result of the shift from the Ottoman millet system (in which people were organised as religious groups, rather than on a territorial basis) to the western nation-state model (Misha 2002; Duijzings 1999). In this context, the shifting names and distinctions of ethnic groups is part of a wider problem of the imposition of modernist classifications of peoples in the Ottoman region, and more recently political crisis and ethnic war (Duijzings 1995). As ethnic distinctions have solidified after the war, so have ideas about religion.

While Albanian nationalists often say 'their only religion is Albanian,' there has been an increased investment in mosques and madrasas from the Middle East. For some, this means a shift towards Islamism, and away from Balkan Islamic practices, as will be discussed further in Chapters 3 and 4. These Balkan practices are increasingly seen as 'pagan,' and therefore haram, forbidden for religious reasons. On the other hand, some of the new practices being adopted are seen as fundamentalist, and this has been used to arrest purported terrorists. The crackdown on terrorism seems to be a way of pleasing the United States, and also of asserting power at home. ${ }^{11}$ Prizren has a reputation in Kosovo for being 'more' Islamic, which for some means a greater interest in Islam, while for others this is seen as radicalisation.

The ease of slipping between ethnic and religious categories, along with the projection of modern categories onto the past in south-east European historiography, explains the complexity of ethnic, religious and linguistic boundaries between groups. Within this regional reconfiguration of ethnicity, shifts in belonging and in the naming of groups extends also to Roma, Ashkali and Egyptians, as I discuss below. 


\section{Introduction}

The formation of Balkan nations can be seen in relation to (and often competition with) one another (Kitromilides 1989). Roma narratives of origin, and in particular the tendency to treat certain groups and labels as fictitious, can be seen as part of wider Balkan ideas of nationhood. If all nations are fluid and constructed (Gellner 1983; Hylland Eriksen 1993), it becomes necessary to ask why, for example, the existence of one nation is treated with far greater scepticism than another. In the past, Macedonian nationhood has been equally contested: Macedonia and its population have been claimed by its Slavic neighbours Serbia and Bulgaria at various points in its history, due to the lack of a clear linguistic border, and did not receive any official status until towards the end of the Second World War (Poulton 2003). This is not just a result of stronger neighbours trying to take land, but rather the mutability of Macedonian identity itself during this period (Yasamee 1995). Today, these lands, though not their inhabitants, are contested by Albanian nationalists, and the name of the country is contested by Greece, which rejects the use of the name 'Macedonia' except for with reference to Greek lands. At the time of my fieldwork the official name of Macedonia was FYROM (the Former Yugoslav Republic of Macedonia). It has since been changed to North Macedonia. These terms are rarely used in everyday speech. The centrality of the name debate shows the importance not just of land, but also of symbols (Danforth 1993).

\section{Roma, Ashkali, Egyptians}

In Prizren, Roma from Terzimahalla differentiate themselves from those who live in Jeta e Re (Shq) / Nevo Jivdipe (Ro), 'New Life.' Jeta e Re is located along the disused railway, in the area which had formerly been called Dushanovo (BCS), the industrial zone in Yugoslav times. A children's centre Iniciativa 6, where I volunteered for a time, was then housed in Jeta e Re. The houses there were built informally, after 1999, and have little infrastructure: there is no tarmac, no streetlamps, intermittent water and electricity supplies, and some houses have no piped water or sewerage. They are far more spread out than the houses in the centre, and the land around them is used for scrap metal collection, wood-chopping, chickens, burning rubbish, and so on. Many, but not all, of the inhabitants are monolingual Albanian speakers, having moved from Albanian villages after the war, and most identify as either Roma or Ashkali.

Roma from Terzimahalla, unlike the inhabitants of Jeta e Re, claim that they arrived with the Turks, and were given the right to remain without fear of attack as they were blacksmiths and made weapons. There is a ritual surrounding a flag given by the Turks (described in Chapter 3), which ensures everyone is aware of this myth of origins, ${ }^{12}$ and many people from Terzimahalla, when asked where they came from, will mention a specific town in Turkey. The relationship to the Turks is used to show Roma as an integral part of Prizren. The centrality of Terzimahalla, in contrast to Jeta e Re, means that inhabitants of Terzimahalla have non-Roma friends, and are more able to mix with others in the town. Although 
the town is small, and Jeta e Re is not so far from the centre, this spatial difference indexes a far greater social difference. As such, the distinction ascribed to those from Jeta e Re by those from Terzimahalla is primarily a socio-cultural one, related to levels of education, religion and prejudice against post-war migrants.

Roma are often called cigani (BCS) or maxhup (Alb), and these derogatory terms are also used as a catch-all, an external term to describe all groups thought of by others as Roma, as well as sets of behaviour and activities stereotypically associated with these groups. In Kosovo, this includes those who now identify variously as Roma, Ashkali and Egyptian. Those who define themselves as Roma, Ashkali and Egyptian tend to be grouped together by international organisations as 'RAE,' three groups which share many of the same problems but are constitutionally recognised as distinct groups.

On the whole, the groups who speak Albanian and live in Albanian areas are far more likely to identify as Egyptian or Ashkali, while those who live in Serb areas identify as Roma. Prizren is thus unusual: while many people identify as Ashkali, there are also many who identify as Roma. On the whole, those who call themselves Ashkali are post-war migrants from Albanian villages, and both Ashkali and Egyptians are Albanian-speaking, and live in Albanian areas. However, they inhabit different parts of Kosovo. In Gjakova, there is a large population of Egyptians, while in Prizren, those from the RAE groups who do not identify as Roma identify as Ashkali. The way these social categories have shifted will be discussed further in Chapter 3.

The boundaries between the three groups (Roma, Ashkali and Egyptians) remain fluid, and many people shift in the way they identify. Roma often say that Ashkali and Egyptians were Roma before the war but now deny their identity. Given that Ashkali and Egyptians rarely speak Romani, it is likely that they were previously referred to as maxhup (Shq), rather than roma. This is not to imply that they have never considered themselves part of the same group, or are not somehow related to Roma. Rather, it seems plausible that in most cases those in rural, Albanian-speaking areas were never exposed to ideas of Romani nationhood before the war, and as such they were unlikely to have developed national consciousness until the changes that came with the war, by which time identifying as Roma in Albanian areas would have seemed increasingly unappealing. ${ }^{13}$ Here, the rise in national consciousness was linked to the rise in linguistic consciousness (see also Friedman 2002a). This indeed could be described as an incidence of 'ethnic unmixing,' whereby the trauma of war, rather than being caused by ethnic difference, in fact creates ethnic difference (Duijzings 2003).

These shifts in identification are also influenced by politics. The emergence of new ethnic categories can be seen as a re-identification encouraged by Milošević in order to reduce the size of the demographic identifying as Albanian (Duijzings 1997), and the distinction between Ashkali and Egyptians is primarily regional, and defined by local political loyalties, rather than by cultural difference (Lichnofsky 2013). Indeed, these new ethnic denominations can be seen as part of a wider ethnicisation of social stratification, which is shaped by regional and local 
loyalties. In addition, international forces' attempts to ensure minority representation in Kosovo have accelerated the distinction of Ashkali from Roma, Egyptians and Albanians (Marushiakova \& Popov 2001).

While the difference between these groups is structured in terms of social distinctions and allegiances to other groups, it is legitimised through different myths of origins. The Terzimahalla narrative of Turkish origins forms part of a different discourse to the Indian myth of origins of the Roma. The Indian myth of origins is fully accepted by most that identify as Roma, and has been mythologised by intellectuals in Prizren, who emphasise connections to present-day India. ${ }^{14}$ Egyptians claim that they are from Egypt, not India, and are therefore distinct from Roma. While some may have identified as Egyptian prior to 1990 (Marushiakova \& Popov 2001), the first organisation of Albanophone Muslims, identified by others as gypsies, into a political group occurred in Ohrid in 1990, and shortly afterwards in Prishtina. Trubeta (2005) argues that this is part of a process to deconstruct gypsy stigma, while constructing a modern national identity. Similarly, Ashkali claim to have originated in Persia, ${ }^{15}$ and therefore also see themselves as distinct from Roma, though those who I know do not deny being related to Roma. Many Roma activists see these new formations as deceptive, and born out of prejudice against Roma. They are problematic for Roma: by reducing the numbers of the Roma 'community,' they are reducing their bargaining power.

The term 'community' in Kosovo is used to refer to an ethnic group, usually a minority ethnic group. In Prizren, 'the communities' (zajednice [BCS] / komunitetya [Ro] / komunitetet [Shq] / topluluklar [Tu]) refers to Turks, Bosniacs, and Roma and Ashkali, while at the level of Kosovo, it would also include Serbs, Egyptians and other native minorities, but not of course members of the large international 'community' in Kosovo. In Kosovo, 'communities' are entitled not just to funds, but also to political representation. ${ }^{16}$ The Assembly of the Republic of Kosovo has 120 members. 100 are directly elected, while the remaining seats are reserved for official minorities, including four seats for Roma, Ashkali and Egyptians. This means that, regardless of the number of votes they receive, one of the Roma parties will get at least one seat. In one sense, this means there is a vested interest in getting support for Roma parties, while on the other, it is often thought to make parties complacent. Roma activists also complain that the political representatives of Ashkali and Egyptian parties encourage people to identify as Ashkali or Egyptian.

The debate about the origins of Roma, Ashkali and Egyptians does not revolve around scientific facts, but is rather based on the varying present-day interests of these groups, reinforced by state and non-state structures. Matras (2013) argues that in addition to being scientifically indisputable, the Indian narrative explains the unusual situation of Roma in Europe, as a scattered nation. The acceptance of the common Indian origins of Roma, then, has the potential to act as a powerful unifying force. In Kosovo, however, the violence, both symbolic and actual, that these groups have faced in recent years are of far greater concern than both scientific proof and pan-Roma unity. 
My research does not concern the origins of, or ethnic distinctions between, RAE. Rather, I am interested in discourses about these distinctions and foundation narratives, and how they are mobilised by my informants in relation to language. Here, local and transnational interests in belonging compete: for some, the unity of the international Romani movement is vital, while for many in Kosovo, their immediate security takes precedence. More generally, origins are contested when people's presence is threatened. The origins of Serbs tend only to become important when they are contested by Albanian claims to have been in the Balkans before them. For Roma, the need to establish a myth of origins relates primarily to present concerns: their need to find a political unity in the face of threatened existence, coupled with a powerlessness to find this unity in the form of a claim to lands in the region they live. Roma from Terzimahalla told me they are from Turkey when they wished to show allegiance and integration in Prizren, and that they are from India to show they are part of a wider group, and there was no contradiction between the two.

This is not to suggest that many of the ancestors of Roma today did not come from what is now India, nor that Romani is not genetically an Indic language. Rather, this is part of a broader ontological debate about originality, related both to historical evidence of origins and to the construction of collective identity through a myth of origins. ${ }^{17}$ From this perspective the construction of a history and a myth of origins may be, but certainly does not have to be, based on historical or linguistic research, and, as all genealogies are selective, they cannot be completely neutral. The categorisation of communities, and the political manipulation of identities, is not merely a fallacy, but under certain circumstances can affect the way groups behave, feel and interact. In this context, language is not an objective attribute of a pre-existing group, but rather language names, linguistic repertoires and language ideologies both construct, and are constructed by, broader politicaleconomic forces.

Identities are always politically constructed, but constructed within certain restrictions, whereby some have a greater ability to construct themselves as authentic than others. I do not wish to imply that the designation of Egyptians, or indeed Macedonians, or any other ethnic group are somehow more constructed or less valid than others on account of their relatively recent genesis (or national 'revival'). Rather, the construction and political manipulations of forms of identification is clearer among certain groups, and with less powerful groups, this leaves them open to accusations of being made up, or masking their true identity. The war increased the salience of ethnic categories, and solidified boundaries between groups, meaning that discrete national categories became the primary way of categorising people. For Serbs and Albanians, this led to an increased salience of myths of origins as a discourse of legitimisation, a claim of originality. For minority groups this meant less flexibility in terms of identity (they could no longer be just 'Albanian-speaking gypsies,' for example), along with an imperative to align with one side or the other. The way origins are mythologised in an 'attempt to establish a link between past and present by asserting historical continuity and 


\section{Introduction}

objectifying this through the concept of descent' (Trubeta 2005:85) is as clear for Roma, Ashkali and Egyptians as it is for Serbs and Albanians. Again, this context has led to an increase in the saliency of myths of origins, and the contestation between them. While Ashkali and Egyptians use Persian and Egyptian origins respectively to delimit their groups, and position themselves on the side of Albanians, in opposition to Serbs and 'gypsies,' Roma in Albanian areas try to envelop all of those seen externally as 'gypsies' into the Romani nation.

The contestation, appropriation and malleability of ethnicity in the region is by no means limited to Roma; the malleability of ethnicity, the rigidification of ethnic boundaries and the shift from social and religious groups to ethnic ones have all been written about extensively with regards to the Balkans, and beyond (cf. Erikson 1995; Daniel 1996; Sundar 2004). Violent wars and changing state borders in the nineties meant growing interest in these issues in the region (Campbell 1998; Gow 1997; Kent 1997; Stokes et al. 1996; Naimark \& Case 2003). Within this focus on ethnicity, language tends to be treated as an objective characteristic of the ethnic group, ${ }^{18}$ and something which, unlike other parts of culture, is beyond human control and manipulation. I intend to show that this is not the case: languages, while being symbolic of ethnic groups, are far from objective, and are open to pressures and manipulations.

\section{Mixture and purity in linguistics and anthropology}

Work on multilingualism in the fields of both sociolinguistics and language contact focuses on the content and structure of language. There is extensive research on the broader effects of language contact on language structures (e.g. Matras 2009; Friedman 1984, 1985b, 2002b). More specifically, theories of codeswitching focus on the details of speech practices, examining how and when people with a multilingual repertoire alternate between languages, as well as the social function and uses of mixing languages (Heller 1988; Myers-Scotton 1988). There is also research on the way social structures and ideologies affect speech practices in the short term, and language structure in the long term (Friedman 2001). These literatures inform my understanding of the social functions of language, and attitudes towards language. However, I depart from these approaches in that I use language to explore deeper social structures.

I build on research on language ideologies (Gal 2005; Kroskrity 2000; Irvine \& Gal 2000), in particular work on the ideological forces behind language standardisation and ideologies which support (and impose) monolingualism (Jaffe 1999; Milroy 2001; Silverstein 1996; Blackledge \& Creese 2010; Woolard 1998). While this field of research broadens the scope of knowledge about how people understand and talk about language, I wish to go further, by asking what the dissonances between ideologies and practices can divulge about the social relations of speakers. A focus on these dissonances, and the political economy in which they are embedded, reveals the role of language and languages within social relations.

Some studies of language socialisation combine the former approach, focusing on the link between society and language, and the latter focusing on language 
ideology, by looking at how language ideology and speech practices are acquired. The acquisition of a multilingual repertoire is dependent on the ideology of, and attitude towards, the relevant languages. People don't just learn to speak; they also learn communicative competence (Hymes 1972) and speech genres (Bakhtin 1986): they learn that certain speech practices are more appropriate than others in certain contexts, and these contexts are understood hierarchically, with nesting distinctions of public and private. In this context, specific speech practices come to be identified as inferior, and this inferiority is then legitimised within broader transformations in social relations.

If the mixture of languages is metonymic of the mixture of cultures, it is also necessary to look at the way the mixture of cultures is ideologically constructed. While linguistics literature looks at the way mixture is enacted through speech practices, anthropological work on mixture has focused on the relationship between ideological understandings of purity and mixture and social structures. Literature on Balkanism discusses how the Balkans are represented as too mixed, in contrast to the 'modern' and categorisable nations of the west (Todorova 1994, 1997; Fleming 2000; Green 2005; Petrović 2008). Here mixture is popularly understood as negative, messy and uncategorised, in contrast to purity. Discourses of cosmopolitanism, on the other hand, posit mixture as a positive feature, in contrast to monocultural backwardness. Cosmopolitanism has been theorised as an ideological stance which is overtly inclusive, while covertly excluding certain groups, namely those of a lower social class (Jansen 2005; Stefansson 2007; Spasić 2011; Grant 2010). As such this cosmopolitan ideological perspective may celebrate mixture, in contrast to purity, but also certain forms of mixture compared with others (Ballinger 2004; Calhoun 2002). I build on this literature to show how ideologies of multilingualism are embedded in power structures, and how multilingualism can be represented both positively and negatively according to who controls the representation.

Recent political shifts in Kosovo have led to a purist language ideology being imported into Romani, which has resulted in the development of an unequal diglossia (see Chapter 5). This purism sits alongside a nostalgic cosmopolitanism, related to the use of a mixed variant of Turkish, as I explore in Chapter 6. Here, the celebration of (lost) cosmopolitanism and the imposition of linguistic purism are not dichotomous: rather, speech practices are understood according to categories of purity and mixture, and subsequently celebrated or denigrated. The hierarchical organisation of speech practices is connected to the hierarchical organisation of social groups, and shifts in the organisation of these groups affect ideological understandings of speech practices, and speech practices themselves.

Speech practices have a social life; they shift in relation to ideologies and power relations, and their meanings vary according to context. My contribution to these fields of research is informed by the work of early Soviet theorists Bakhtin and Voloshinov. Bakhtin introduces speech genres as follows: '(e)ach separate utterance is individual, of course, but each sphere in which language is used develops its own relatively stable types of these utterances' (Bakhtin 1986:60). I analyse the way speech genres are formed, and changed by a particular group. 


\section{Introduction}

Voloshinov argues that '(i)t should be one of the tasks of the study of ideology to trace [the] social life of the verbal sign' (Voloshinov 1973:27). By taking not just the sign, but also its historical trajectory, we can see how meaning is formed within social relations. The multiaccentuality of the sign, a sign's potential to have multiple meanings, and the space for conflict within this multiplicity, can be used to elicit 'a little arena for the clash and criss-crossing of differently orientated social actions' (Voloshinov 1973:41). These theories are crucial, not only because they incorporate diachronic and synchronic aspects of language - the historical trajectory of signs - but also because they examine these trajectories in terms of structural inequalities.

In order to understand language, we need more than an understanding of the social context or background: the ethnographic study of language can open up a wealth of ways to study social life itself. By combining and incorporating approaches from linguistics and anthropology, especially theories about the effect of ideology on speech practices and ideological interpretations of speech practices, I hope to further knowledge about how language is used within unequal power structures.

\section{Book layout}

This book argues that language can be used to study social relations. Rather than looking at how the study of language enriches the study of society, or how a knowledge of society informs the study of language, I look at how society can be studied through language. Language and society are not just contexts of one another, but are in fact mutually constitutive. As such changes in speech practices are closely connected to changes in social relations. This leads me to ask how social hierarchies are articulated through linguistic ideology and speech practices at different scales.

In the first part of the book I focus on the relationship between changes in linguistic repertoires and political and economic changes in Kosovo since the founding of socialist Yugoslavia, relating this to contemporary social relations. Taking Roma in Prizren as my starting point, I examine how broader political forces affect smaller scale social relations and language politics. Chapter 1 describes how I set about investigating these issues, gives details of my fieldwork and explains how I used language learning as my main method. Taking the idea of the ethnographer as a novice or learner, I look at how the processes of language acquisition and language socialisation can be used by the ethnographer to probe further into the hierarchies of speech practices and language ideologies. Chapter 2 asks how language politics has shaped Roma and Durmish Aslano, the Romani organisation I volunteered with in Prizren, diachronically. The chapter discusses the conditions in which the organisation came to be formed, and how it has been reconstituted over time, locating this trajectory within the literature on Yugoslav and Kosovo history, language policies and theories of memory and ethnicity. Chapter 3 investigates the contemporary role of Durmish Aslano, focusing on a project to protect Romani intangible cultural heritage. This chapter discusses how language and 
policies are translated and transformed as they flow from western funders to eastern projects, and how this relates to the politics of recognition and redistribution.

The second part of the book focuses on how language ideologies and discourses of purity and hybridity relate to speech practices. Given the place of Roma amidst external forces, and the social inequality discussed in the first part of the book, this part looks at how Roma represent themselves both linguistically and extralinguistically, and how this reflects and reproduces a Balkanist worldview. Roma are widely perceived as in-between and out-of-place, and below other groups. When this perception is internalised, it is both reproduced and changed. Chapter 4 looks at the Romani dramas performed in Prizren. Paradoxically, the dramas which aim to valorise Romani identity also perform a negative image of Roma. By examining the representation of Roma and the 'gypsy' image in the dramas, and exploring how this shifting representation of self and other is enacted off stage, we can see how this representation forms part of a broader Balkanist schema of representation, performed dramatically through the use of the tragicomic form. Chapter 5 moves on from Roma in representation to Romani speech practices, looking at how certain practices are perceived to be better than others, how the distinction between good and bad speech practices is produced and how a Romani standard is being produced and legitimised in Prizren. As such it investigates the symbiotic relationship between ideology and practices. Chapter 6 focuses on another paradox: in parallel to the process of standardisation discussed in Chapter 5, there is also extensive positive valence afforded to the mixture of languages. Purism, ridding Romani of alien words, is seen as crucial, but at the same mixture, in the form of cosmopolitanism and multilingualism, is valorised. People acknowledge the local variant of Turkish as mixed, and embrace this mixture, within the confines of the speech genre of nostalgia. These speech practices used to be neutral within the town, and excluded those from outside, but since the war and major shifts in power relations, they have come to signify nostalgia for this pre-war sedentarist urban cosmopolitanism. The concluding chapter draws together the discussion of language and change in the first part, and the relationship between ideology and speech practices in the second to question the way Roma are positioned and perceived as being 'in-between,' not quite fitting into any category.

\section{Notes}

1 The language (or group of variants) formerly called Serbo-Croat is now known as Bosnian, Croatian, Serbian or Montenegrin, depending primarily on the ethnicity of the speaker rather than any particular linguistic features.

2 I use 'gypsy' as the closest translation for cigan, and similarly derogatory terms in other languages. In the Balkans, it does not have the same implication of a travelling lifestyle that it does in the UK, but rather refers to a negative image of the ethnic group. In addition to using it as a translation, throughout the book I will use the term gypsy, not capitalised, to indicate a negative image of the group, in contrast to Roma, a neutral term for the ethnic group.

3 Where possible I use English versions of place names to avoid choosing either Albanian or Serbian versions. 


\section{Introduction}

4 Bosniac (bošnjak) is a relatively recent term for Muslims Slavs. It replaced the ethnonational designation Bosnians Muslim in Bosnia, and has spread throughout the region.

5 This is true for those who attended school: many, though by no means all, of the men I spoke to had attended school and were literate, but this was rarely the case for women. In the pre-war era, boys were sometimes kept back from secondary school in order to learn to be musicians. Most Roma women of this generation were kept at home to help with housework, childcare and care of the elderly. The practice of keeping girls at home now seems less common in Terzimahalla, but continues in other mahallas. While firm statistics are elusive, my impression is that this is similar to the situation among Albanian girls.

6 Since some churches were built in Kosovo during the Milošević era as a sign of Serbian hegemony (for example in Prishtina), this was used to legitimise retaliations against all Serbian churches (new or old) after the war. While more accept the presence of older churches, there is an ongoing debate over whether new churches, built in the Milošević era, should be allowed to remain (see Kraja 2016).

7 The organisation Ec ma nryshe is one of the main proponents of ending this protection of Serb monuments, suggesting it would be better to focus instead on preventing the destruction of other buildings which makes way for new developments. (See for example Ec ma ndryshe 2015.)

8 This is not, of course, unique to the Balkans, but rather takes on a particular form in the Balkans.

9 A group of Roma living primarily in Germany.

10 Matras (2014) relates the etymology of Koroxaj for 'Turkey' to Romani contact with the Karakhanid dynasty in the tenth and eleventh centuries, suggesting that this was the first time they encountered Muslims, and they subsequently labelled all Muslims with derivations of Karakhanid.

11 See for example an article in The Guardian by the then Prime Minister and former KLA leader Thaçi (2014), where he refutes the idea that Kosovo breeds jihadis and promises to repress all jihadi movements.

12 I use myth to refer to the way historical events, factual or fictional, are constructed and narrated as something of importance to a particular group of people, rather than in the lay sense of a story which is fictional or untrue (Kolstø 2005; Duijzings 1999; Duijzings 2005).

13 For a comparative view of Vlachs, a group who, despite certain distinctive features, never mobilised into a national movement see Winnifrith (1992).

14 This takes the form of women and girls wearing saris for Romani events, using the imagery of the Taj Mahal in publications and drawing comparisons between Indian soap operas and their own lives.

15 Some also claim Roman and Palestinian origins (Marushiakova \& Popov 2001).

16 They also have their own star on the flag of Kosovo.

17 See Clifford (1988) for a discussion of this predicament with regard to Mashpee Native Americans.

18 Discussions over the division of Serbo-Croat are an exception in that this division is widely debated. However treating the distinction between some languages as natural and others as constructed in fact reinforces the idea that languages can be objective defined (cf. Hodges 2016; Greenberg 2004; Kordić 2010). 


\section{Bibliography}

Abercrombie, A. forthcoming. Diglossic learning: Romani language in Prizren. In: Tarsoly, E. \& Ćalić, J. (Eds.), Fashioning Language. The Politics of Teaching and Learning Languages. London: UCL Press.

Abu-Lughod, L. \& Lutz, C. 1990. Introduction: Emotion, discourse, and the politics of everyday life. In: Lutz, C. \& Abu-Lughod, L. (Eds.), Language and the Politics of Emotion. Cambridge: Cambridge University Press. Pp. 1-23.

Abu-Lughod, L. 2002. Do Muslim women really need saving? Anthropological reflections on cultural relativism and its others. American Anthropologist, 104(3), 783-790.

Acković, D. 2009. Romi u Beogradu. Istorija, kultura i tradicija Roma u Beogradu. Beograd: Rominterpres.

Adams, L. 2013. Ethnicity and the politics of heritage in Uzbekistan. Central Asian Survey, $32(2), 115-133$.

Agar, M. 1991. The biculture in bilingual. Language in Society, 20(02), 167-182.

Agar, M. 2009. A linguistics for ethnography. Why not second Languaculture learning and translation? Journal of Intercultural Communication, 16. Available at: www.immi.se/ intercultural/nr16/agar.htm. Accessed 11/04/20.

Agha, A. 2003. The social life of cultural value. Language and Communication, 23(3-4), 231-273.

Allcock, J. B. 2000. Explaining Yugoslavia. London: Hurst \& Co.

Ananiadis, G. 2002. Carl Schmitt on Kosovo, or, taking war seriously. In: Bjelić, D. I. \& Savić, O. (Eds.), Balkan as Metaphor: Between Globalization and Fragmentation. Cambridge, MA: MIT Press. Pp. 117-162.

Anderson, B. 1983. Imagined Communities. London: Verso.

Anderson, D. 1996. Bringing civil society to and uncivilised place. In: Hann, C. \& Dunn, E. (Eds.), Civil Society: Rethinking Western Models. London: Routledge. Pp. 99-120.

Annamalai, E. 1989. The linguistic and social dimensions of purism. In: Jernudd, B. H. \& Shapiro, M. J. (Eds.), The Politics of Language Purism. Berlin/New York: Walter de Gruyter. Pp. 225-231.

Arandarenko, M. \& Golicin, P. 2007. Serbia. In: Deacon, B. \& Stubbs, P. (Eds.), Social Policy and International Interventions in South East Europe. Cheltenham: Edward Elgar Publishing. Pp. 167-186.

Archer, R. 2016. 'Paid for by the workers, occupied by the bureacrats': Housing inequalities in 1980s Belgrade. In: Archer, R., Duda, I. \& Stubbs, P. (Eds.), Social Inequalities and Discontent in Yugoslav Socialism. London/New York: Routledge. Pp. 58-76. 


\section{Bibliography}

ASK. 2015. Kosovo in Figures 1. General Statistics. Prishtina: Kosovo Agency of Statistics. Available at: http://ask.rks-gov.net/en/kosovo-agency-of-statistics. Accessed 01/02/17. ASK. 2016. Results of the Kosovo 2015. Labour Force Survey. Prishtina: Kosovo Agency of Statistics. Available at: http://ask.rks-gov.net/en/kosovo-agency-of-statistics. Accessed 01/02/17.

Baker, C. 2012. Prosperity without security: The precarity of interpreters in postsocialist, postconflict Bosnia-Herzegovina. Slavic Review, 71(4), 849-872.

Baker, D. 2015. The queer gypsy. Roma Rights Journal. www.errc.org/roma-rights-journ al/roma-rights-2-2015-nothing-about-us-without-us-roma-participation-in-policy-m aking-and-knowledge-production/4433/14. Accessed 12/04/20

Bakhtin, M.M. 1986. Speech genres and other late essays (Holquist, M. and Emerson, C.[Eds.] McGee, V.W. [Trans]). Austin: University of Texas Press.

Bakić-Hayden, M. 1995. Nesting orientalisms: The case of former Yugoslavia. Slavic Review, 54(4), 917-931.

Ballinger, P. 2004. 'Authentic hybrids' in the Balkan Borderlands. Current Anthropology, 45(1), 31-60.

Baučić, I. 1971. Vanjske migracije radne snage kao Faktor socijalnoekonomskih promjena u seoskim sredinama. Sociologija i Prostor, 31-32, 127-140.

Bauman, R. \& Briggs, C. L. 2000. Language philosophy and language as ideology: John Locke and Johann Gottfried Herder. In: Kroskrity, P. V. (Ed.), Regimes of Language: Ideologies, Polities, and Identities. Santa Fe, NM: School of American Research Press. Pp. 139-204.

BBC. 1999. Analysis: Gypsies 'caught in the middle'. Available at: http://news.bbc.co.uk /1/hi/world/europe/386945.stm. Accessed 12/04/2020.

Beasley von Burg, A. 2009. Free to move but nowhere to go: The European Union and the Roma population. Paper Presented at the European Union Studies Association Conference, Los Angeles, CA, April 22, 2009. Available at: http://aei.pitt.edu/33026/. Accessed 12/04/2020.

Beha, A. 2014. Minority rights: An opportunity for adjustment of ethnic relations in Kosovo. JEMIE, 13, 85-110.

Beissinger, M. H. 2001. Occupation and ethnicity: Constructing identity among professional Romani (Gypsy) musicians in Romania. Slavic Review, 60(1), 24-49.

Beltran, C. 2004. Patrolling borders: Hybrids, hierarchies and the challenge of mestizaje. Political Research Quarterly, 57(4), 597-607.

Bhabha, H. K. \& Rutherford, J. 2006. Third space. Multitudes, 3, 95-107.

Blackledge, A. \& Creese, A. 2010. Multilingualism: A Critical Perspective. London: Bloomsbury Publishing.

Bloch, M. 1991. Language, anthropology and cognitive science. Man, 26(2), 183-198.

Block, D. 2012. Unpicking agency in sociolinguistics research with migrants. In: Gardner, S. \& Martin-Jones, M. (Eds.), Multilingualism, Discourse, and Ethnography. London: Routledge. Pp. 54-67.

Blommeart, J. 2003. Commentary: A sociolinguistics of globalization. Journal of Sociolinguistics, 7(4), 607-623.

Blumi, I. 2002. The role of education in the formation of Albanian identity and its myths. In: Schwandner-Sievers, S. \& Fischer, B. J. (Eds.), Albanian Identities: Myth and History. London: Hurst. Pp. 49-59.

Bonfiglioli, C. 2015. Gendered citizenship in the global European periphery: Textile workers in post-Yugoslav states. Women's Studies International Forum, 49, 57-65. 
Bortolotto, C. 2007. From objects to processes: UNESCO's intangible cultural heritage. Journal of Museum Ethnography, 19, 21-33.

Bourdieu, P. 1990. The Logic of Practice. Palo Alto: Stanford University Press.

Bourdieu, P. 1991. Language and Symbolic Power. Cambridge: Polity Press.

Bourdieu, P. 2004. The peasant and his body. Ethnography, 5(4), 579-599.

Boym, S. 2002. The Future of Nostalgia. New York: Basic Books.

Bracewell, W. \& Drace-Francis, A. 1999. South-Eastern Europe: History, concepts, boundaries. Balkanologie, 3(2), 47-66.

Bradley, J. 1988. Yanyuwa: 'Men speak one way, women speak another'. Aboriginal Linguistics, 1, 126-134.

Brandstädter, S. 2007. Transitional spaces: Postsocialism as a cultural process. Critique of Anthropology, 27(2), 131-145.

Bringa, T. 1995. Being Muslim the Bosnian Way: Identity and Community in a Central Bosnian Village. Princeton: Princeton University Press.

Brooks, E. C. 2012. The possibilities of Romani feminism. Signs, 38(1), 1-11.

Brubaker, R. 2006. Nationalist Politics and Everyday Ethnicity in a Transylvanian Town. Princeton: Princeton University Press.

Brunnbauer, U. 2004. (Re)Writing History. Historiography in Southeast Europe After Socialism. Münster: Lit-Verlag.

Bucholtz, M. 2003. Sociolinguistic nostalgia and the authentication of identity. Journal of Sociolinguistics, 7(3), 398-416.

Bugarski, R. 1991. Language in Yugoslavia: Situation, policy, planning. In: Bugarski, R. \& Hawkesworth, C. (Eds.), Language Planning in Yugoslavia. Ohio: Slavica Publishers. Pp. 9-28.

Burnett, J. H. 1974. On the analog between culture acquisition and ethnographic method. Council on Anthropology and Education Quarterly, 5(1), 25-29.

Byram, M. \& Esarte-Sarries, V. 1991. Investigating Cultural Studies in Foreign Language Teaching: A Book for Teachers (No. 62). Bristol: Multilingual Matters Limited.

Byram, M. 1997. Introduction: Towards a pedagogical framework for visits and exchanges. In: Byram, M. (Ed.), Face to Face: Learning 'Language-and-Culture' Through Visits and Exchanges. London: Centre for Information on Language Teaching and Research (CILT). Pp. 3-16.

Calhoun, C. J. 2002. The class consciousness of frequent travelers: Toward a critique of actually existing cosmopolitanism. The South Atlantic Quarterly, 101(4), 869-897.

Campbell, D. 1998. National Deconstruction: Violence, Identity, and Justice in Bosnia. Minneapolis: University of Minnesota Press.

Canagarajah, S. 2013. Translingual Practice: Global Englishes and Cosmopolitan Relations. Oxford: Routledge.

Carrier, J. 2015. The concept of class. In: Carrier, J. G. \& Kalb, D. (Eds.), Anthropologies of Class: Power, Practice, and Inequality. Cambridge: Cambridge University Press. Pp. 28-40.

Chari, S. \& Verdery, K. 2009. Thinking between the posts: Postcolonialism, postsocialism, and ethnography after the Cold War. Comparative Studies in Society and History, 51(1), 6-34.

Clifford, J. 1988. The Predicament of Culture. Cambridge, MA: Harvard University Press.

Cocozzelli, F. P. 2007. Kosovo. In: Deacon, B. \& Stubbs, P. (Eds.), Social Policy and International Interventions in South East Europe. Cheltenham: Edward Elgar Publishing. Pp. 203-220. 
Cocozzelli, F. P. 2009. The Kosovo conflict (1981-1999) and the creation of ethnicized institutions. In: Cocozzelli, F. \& Chung, P. S. (Eds.), War and Social Welfare: Reconstruction After Conflict. New York: Palgrave Macmillan. Pp. 33-60.

Cohen, A. P. 1985. The Symbolic Construction of Community. London: Ellis Horwood.

Collins, P. H. 1998. It's all in the family: Intersections of gender, race, and nation. Hypatia, 13(3), 62-82.

Courthiade, M. 1989. La langue Romani (Tsigane): Évolution, standardisation, unification, réforme. In: Fodor, I. \& Hagège, C. (Eds.), Hamburg Language Reform. History and Future, Vol IV. Hamburg: Helmut Buske Verlag. Pp. 87-110.

Cowan, J., Dembour, M. \& Wilson, R. 2001. Introduction. In: Cowan, J., Dembour, M. \& Wilson, R. (Eds.), Culture and Rights: Anthropological Perspectives. Cambridge: Cambridge University Press. Pp. 1-26.

Creed, G. 2006. Reconsidering community. In: Creed, G. (Ed.), The Seductions of Community: Emancipations, Oppressions, Quandaries. Santa Fe: School of American Research Press. Pp. 3-22.

Crenshaw, K. 1989. Demarginalizing the intersection of race and sex: A black feminist critique of antidiscrimination doctrine, feminist theory and antiracist politics. University of Chicago Legal Forum, 1989, 8. Available at: https://chicagounbound.uchicago.edu/ uclf/vol1989/iss 1/8. Accessed 12/04/20

Crystal, D. 2008. A Dictionary of Linguistics and Phonetics. 6th edition. Oxford: Blackwell.

Danforth, L. M. 1993. Claims to Macedonian identity: The Macedonian question and the breakup of Yugoslavia. Anthropology Today, 9(4), 3-10.

Daniel, E. V. 1996. Crushed glass: A counterpoint to culture. In: Daniel, E. V. (Ed.), Charred Lullabies: Chapters in an Anthropography of Violence. Princeton: Princeton University Press. Pp. 194-212.

Daniel, O. 2007. Gastarbajteri: Rethinking Yugoslav economic migrations towards the European North-West through transnationalism and popular culture. In: Ellis, S. G. \& Klusáková, L. A. (Eds.), Imagining Frontiers, Contesting Identities. Pisa, Italy: Edizioni Plus, Pisa University Press. Pp. 277-302.

de Beauvoir, S. 2014 [1949]. The Second Sex. London: Vintage Books.

de Swaan, A. 1995. Widening circles of identification: Emotional concerns in sociogenetic perspective. Theory, Culture, and Society, 12(2), 25-39.

Deacon, B. \& Stubbs, P. 2007. Transnationalism and the making of social policy in South East Europe. In: Deacon, B. \& Stubbs, P. (Eds.), Social Policy and International Interventions in South East Europe. Cheltenham: Edward Elgar Publishing. Pp. 1-21.

Despalatović, E. M. 1975. Ljudevit Gaj and the Illyrian Movement. New York: Colombia University Press.

Ditchev, I. 2002. The Eros of identity. In: Bjelić, D. I. \& Savić, O. (Eds.), Balkan as Metaphor: Between Globalization and Fragmentation. Cambridge, MA: MIT Press. Pp. $235-250$.

Dobreva, N. 2007. Constructing the 'Celluloid Gypsy': Tony Gatlif and Emir Kusturica's Gypsy films in the context of New Europe. Romani Studies, 17(2), 141-153.

Đorđević, D. 1975. Balkan versus European enlightenment: Parallelisms and dissonances. East European Quarterly, 9(4), 486-497.

Douglas, M. 1966. Purity and Danger: An Analysis of Concepts of Pollution and Taboo. London: Routledge.

Duijzings, G. 1995. The exodus of Letnica-Croatian refugees from Kosovo in western Slavonia A chronicle. Narodna Umjetnost: Hrvatski Časopis Za Etnologiju $i$ Folkloristiku, 32(2), 152-152. 
Duijzings, G. 1997. The making of Egyptians in Kosovo and Macedonia. In: Govers, C. \& Vermeulen, H. (Eds.), The Politics of Ethnic Consciousness. Basingstoke: Palgrave Macmillan UK. Pp. 194-222.

Duijzings, G. 1999. Religion and the Politics of Identity in Kosovo. London: Hurst.

Duijzings, G. 2003. Ethnic unmixing under the aegis of the West: A transnational approach to the breakup of Yugoslavia. Bulletin of the Royal Institute for Inter-Faith Studies, $5(2), 1-16$.

Duijzings, G. 2005. New myths are needed: Reconciliation in Kosovo as an intellectual challenge. Studia Historica Nitriensia, 12, 263-267.

Duijzings, G. 2010. From bongo bongo to Boston via the Balkans: Anthropological contributions to the study of urban transformations in southeastern Europe. In: Bohn, T. M. \& Calic, M. J. (Eds.), Urbanisierung und Stadtentwicklung in Südosteuropa vom 19. bis zum 21. Jahrhundert. 47. Munich: Otto Sagner (Südosteuropa-Jahrbuch 37). Pp. 93-132.

Dunn, C. D. 1999. Toward the study of communicative development as a life-span process. Anthropology and Education Quarterly, 30(4), 451-454.

EC Ma Ndryshe. 2015. Erroneous: An Analysis of Numerous and Continuous Faults in Cultural Heritage. Series Analysis "What Went Wrong”? Prishtina: KFOS.

Edwards, J., Evans, G. \& Smith, K. 2012. Introduction: The middle class-ification of Britain. Focaal, 2012(62), 3-16.

Elshani, I. 2011. Romani problematika. Yekhipe, 40, 7-9.

Erikson, K. 1995. Notes on trauma and community. In: Caruth, C. (Ed.), Trauma. Explorations in Memory. Baltimore/London: The John Hopkins University Press. Pp. 183-199.

Esbenshade, R. S. 1995. Remembering to forget: Memory, history, national identity in postwar East-Central Europe. Representations, 49(1), 72-96.

Evans, G. 2006. Learning, violence and the social structure of value. Social Anthropology, 14(2), 247-259.

Ferguson, J. \& Gupta, A. 2002. Spatializing states: Toward an ethnography of neoliberal governmentality. American Ethnologist, 29(4), 981-1002.

Ferguson, J. 2006. Global Shadows: Africa in the Neoliberal World Order. Durham: Duke University Press.

Fernandez, J. W. \& Taylor Huber, M. 2001. Introduction: The anthropology of irony. In: Fernandez, J. W. \& Taylor Huber, M. (Eds.), Irony in Action: Anthropology, Practice and Modern Imagination. Chicago/London: University of Chicago Press. Pp. 1-41.

Fleming, K. E. 2000. Orientalism, the Balkans, and Balkan historiography. The American Historical Review, 105(4), 1218-1233.

Foster, V. A. 2004. The Name and Nature of Tragicomedy. Hants: Ashgate Publishing Ltd.

Fraser, N. 2000. Rethinking recognition. New Left Review, 3, 107-120.

Friedman, V. A. 1982. Balkanology and Turcology: West Rumelian Turkish in Yugoslavia as reflected in prescriptive grammar. Studies in Slavic and General Linguistics, 2, 1-77.

Friedman, V. A. 1984. Romani te in a Balkan context. Językowe Udia Balkanistyczne, 1, 39-48.

Friedman, V. A. 1985a. Problems in the codification of a standard Romani literary language. Papers from the Fourth and Fifth Annual Meetings: Gypsy Lore Society. New York: Gypsy Lore Society.

Friedman, V. A. 1985b. Balkan Romani modality and other Balkan languages. Folia Slavica, 7(3), 381-389. 
Friedman, V. A. 1991. Case in Romani: Old grammar in new affixes. The Journal of the Gypsy Law Society, 1(2), 85-102.

Friedman, V. A. 2001. Romani multilingualism in its Balkan context. Sprachtypologie und Universalienforschung, 54(2), 148-161.

Friedman, V. A. 2002a. Romani as minority language, as a standard language, and as a contact language: Comparative legal, sociolinguistic, and structural approaches. Proceedings of the Eighth Nordic Conference on Bilingualism, Stockholm University, Stockholm.

Friedman, V. A. 2002b. Boundaries and borders in Balkan Slavic. International Journal of Slavic Linguistic and Poetics, 44-45, 161-173.

Friedman, V. A. 2005. The Romani language in Macedonia in the third millennium: Progress and problems. In: Matras, Y. (Ed.), Romani in Contact: The History, Structure, and Sociology of a Language. Amsterdam: Benjamins. Pp. 203-217.

Gal, S. 1978. Peasant men can't get wives: Language change and sex roles in a bilingual community. Language in Society, 7(01), 1-16.

Gal, S. 1989. Language and political economy. Annual Review of Anthropology, 18(1), 345-367.

Gal, S. 1991. Bartok's funeral: Representations of Europe in Hungarian political rhetoric. American Ethnologist, 18(3), 440-458.

Gal, S. \& Irvine, J. T. 1995. The boundaries of languages and disciplines: How ideologies construct difference. Social Research, 62(4), 967-1001.

Gal, S. 2005. Language ideologies compared. Journal of Linguistic Anthropology, 15(1), 23-37.

Gal, S. 2006a. Contradictions of standard language in Europe: Implications for the study of practices and publics. Social Anthropology, 14(2), 163-181.

Gal, S. 2006b. Linguistic anthropology. In: Brown, K. (Ed.), Encyclopedia of Language and Linguistics. 2nd edition, volume 7. Amsterdam: Elsevier. Pp. 171-185.

Gal, S. \& Kligman, G. 2012. The Politics of Gender After Socialism: A ComparativeHistorical Essay. Princeton: Princeton University Press.

Gal, S. \& Woolard, K. 2014. Languages and Publics: The Making of Authority. London: Routledge.

Gamonte, D. S. 2013. Diasporic Roma Students: Performing Ethnic Identity. Sense of Displacement and In-between-ness. Unpublished doctoral thesis. Budapest: Central European University.

Garcia, O. \& Mason, L. 2009. Where in the world is US Spanish? Creating a space of opportunity for US Latinos. In: Harbert, W. (Eds.), Language and Poverty. Bristol: Multilingual Matters. Pp. 78-101.

García, O. \& Wei, Li. 2013. Translanguaging: Language, Bilingualism and Education. New York: Springer.

Garrett, P. B. 2005. What a language is good for: Language socialization, language shift, and the persistence of code-specific genres in St. Lucia. Language in Society, 34(03), 327-361.

Garrett, P. B. 2008. Researching language socialization. In: May, S. \& Hornberger, N. H. (Eds.), Encyclopedia of Language and Education: Language Policy and Political Issues in Education. New York: Springer. Pp. 3386-3398.

Gay y Blasco, P. 2008. Picturing 'Gypsies' interdisciplinary approaches to Roma representation. Third Text, 22(3), 297-303.

Gellner, E. 1983. Nations and Nationalism. Oxford: Blackwell. 
Goldstein, L. 1990. The linguistic interest of verbal humor. Humor-International Journal of Humor Research, 3(1), 37-52.

Goldstein, P. 2013. Building Bridges: NGOs, Associations, Movements, Facebook Groups, and the State of Civil Society in Mostar and Novi Sad. Unpublished doctoral thesis. Manchester: University of Manchester.

Goldsworthy, V. 2002. Invention and in(ter)vention: The rhetoric of balkanization. In: Bjelić, D. I. \& Savić, O. (Eds.), Balkan as Metaphor: Between Globalization and Fragmentation. Cambridge, MA: MIT Press. Pp. 23-38.

Golovko, E. 2003. Language contact and group identity: The role of "folk" linguistic engineering. In: Matras, Y. \& Bakker, P. (Eds.), The Mixed Language Debate: Theoretical and Empirical Advances. Berlin/New York: Walter de Gruyter. Pp. 177-208.

Gorski, G. 2005. The Shutka Book of Records: Sampionite od Sutka (Knjiga rekorda Sutke) CEL FILM. Available at: www.youtube.com/watch?v=RPJnukaw-3Q. Acessed 12/04/20.

Gow, J. 1997. After the flood: Literature on the context, causes and course of the Yugoslav War reflections and refractions. Slavonic and East European Review, 75(3), 446-484.

Grant, B. 2010. Cosmopolitan Baku. Ethnos, 75(2), 123-147.

Grdešić, M. 2015. Workers and unions after socialism. In: Horvat, S. \& Štiks, I. (Eds.), Welcome to the Desert of Post-Socialism: Radical Politics After Yugoslavia. London: Verso. Pp. 65-84.

Green, S. F. 2005. Notes from the Balkans: Locating Marginality and Ambiguity on the Greek-Albanian Border. Princeton: Princeton University Press.

Greenberg, J. 2011. On the road to normal: Negotiating agency and state sovereignty in postsocialist Serbia. American Anthropologist, 113(1), 88-100.

Greenberg, R. D. 2004. Language and Identity in the Balkans: Serbo-Croatian and Its Disintegration. Oxford: Oxford University Press.

Grosjean, F. 2008. Studying Bilinguals. Oxford: Oxford University Press.

Gumperz, J. \& Hymes, D. 1972. Directions in Sociolinguistics: The Ethnography of Communication. New York: Holt, Reinhart and Winston.

Gupta, A. \& Ferguson, J. 1992. Beyond 'culture': Space, identity, and the politics of difference. Cultural Anthropology, 7(1), 6-23. [reprinted in Gupta, A. \& Ferguson, J. (Eds.) 1997. Culture, power, place. Durham: Duke University Press.]

Guthke, K. S. 1966. Modern Tragicomedy. New York: Random House.

Gutiérrez, K. D., Baquedano-López, P. \& Tejeda, C. 1999. Rethinking diversity: Hybridity and hybrid language practices in the third space. Mind, Culture, and Activity, 6(4), 286-303.

Guy, W. 2001. Between past and Future: The Roma of Central and Eastern Europe. Hatfield: University of Hertfordshire Press.

Haliliuc, A. 2015a. What is so funny about the death of Mr. Lăzărescu? The Journal of Popular Culture, 48(1), 154-167.

Haliliuc, A. 2015b. Manele music and the discourse of balkanism in Romania. Communication, Culture and Critique, 8(2), 290-308.

Halwachs, D. W. 2011. Language planning and media: The case of Romani. Current Issues in Language Planning, 12(3), 381-401.

Halwachs, D. W. 2012a. Linguistic diversity, dominated languages and the Internet: The case of Romani. In: Linguistic and Cultural Diversity in Cyberspace. Proceedings of the 2nd International Conference. Paris/Moscow: UNESCO. Pp. 272-281. 


\section{Bibliography}

Halwachs, D. W. 2012b. Romani teaching: Some general considerations based on model cases. European Yearbook of Minority Issues Online, 9(1), 249-269.

Hann, C. 1996. Political society and civil anthropology. In: Hann, C. \& Dunn, E. (Eds.), Civil Society: Rethinking Western Models. London: Routledge. Pp. 1-26.

Haspelmath, M. 2006. Against markedness (and what to replace it with). Journal of Linguistics, 42(01), 25-70.

Haugen, E. 1966. Dialect, language, nation. American Anthropologist, 68(4), 922-935.

Helbig, A. 2010. The dialogics of development: NGOs, ethnopolitics, and Roma in Ukraine. In: D'Anieri, P. (Ed.), Orange Revolution and Aftermath: Mobilization, Apathy, and the State in Ukraine. Baltimore: Woodrow Wilson International Center for Scholars/John Hopkins University Press. Pp. 254-273.

Heller, M. 1988. Introduction. In: Heller, M. (Ed.), Codeswitching: Anthropological and Sociolinguistic Perspectives. Berlin/New York/Amsterdam: Mouton de Gruyter. Pp. 53-76.

Heller, M. 2003. Globalization, the new economy, and the commodification of language and identity. Journal of Sociolinguistics. Special Issue: Sociolinguistics and Globalization, 7(4), 473-492.

Heller, M. 2012. Rethinking sociolinguistic ethnography: From community and identity to process and practice. In: Gardner, S. \& Martin-Jones, M. (Eds.), Multilingualism, Discourse, and Ethnography. London: Routledge. Pp.24-33.

Helms, E. 2010. The gender of coffee: Women and reconciliation initiatives in post-war Bosnia and Herzegovina. Focaal, 2010(57), 17-32.

Henig, D. 2012. Knocking on my neighbour's door: On metamorphoses of sociality in rural Bosnia. Critique of Anthropology, 32(1), 3-19.

Herzfeld, M. 2001. Irony and power: Toward a politics of mockery in Greece. In: Fernandez, J. W. \& Taylor Huber, M. (Eds.), Irony in Action: Anthropology, Practice \& Modern Imagination. Chicago/London: University of Chicago Press. Pp. 63-86.

Herzfeld, M. 2004. Cultural Intimacy: Social Poetics in the Nation-State. New York: Routledge.

Herzfeld, M. 2007. Deskilling, 'dumbing down,' and the auditing of knowledge in the practical mastery of artisans and academics: An ethnographer's response to a global problem. In: Harris, M. (Ed.), Ways of Knowing. New Approaches in the Anthropology of Experience and Learning. New York/Oxford: Berghahn Books. Pp. 91-113.

Herzfeld, M. 2009. The cultural politics of gesture: Reflections on the embodiment of ethnographic practice. Ethnography, 10(2), 131-152.

Heyd, U. 1954. Language Reform in Modern Turkey. Jerusalem: Israel Oriental Society.

Hill, J. 1998. "Today there is no respect": Nostalgia, "respect," and oppositional discourse in Mexicano (Nahuatl) language ideology. In: Schieffelin, B. B., Woolard, K. A. \& Kroskrity, P. V. (Eds.), Language Ideologies: Practice and Theory. Oxford: Oxford University Press. Pp. 68-86.

Hill, J. H. \& Hill, K. C. 1980. Mixed grammar, purist grammar, and language attitudes in modern Nahuatl. Language in Society, 9(03), 321-348.

Hill, J. H. \& Coombs, D. M. 1982. The vernacular remodelling of national and international languages. Applied Linguistics, 3(3), 224-234.

Hirst, D. L. 1984. Tragicomedy. London/New York: Methuen.

Hodges, A. 2016. Croatian language standardization and the production of nationalized political subjects through language? Perspectives from the social sciences and humanities. Etnološka Tribina: Journal of Croatian Ethnological Society, 46(39), 3-45. 
Hoepken, W. 1998. War, memory, and education in a fragmented society: The case of Yugoslavia. East European Politics and Societies, 13(1), 190-227.

Hoeppe, G. 2007. Conversations on the Beach: Fisherman's Knowledge, Metaphor and Environmental Change in South India. New York/Oxford: Berghahn Books.

Homer, S. 2006. "The Roma do not exist": The Roma as an object of cinematic representation and the question of authenticity. Gramma, Journal of Theory and Criticism, 14, 183-198.

Human Rights Watch. 1999. Federal Republic of Yugoslavia: Abuses against Serbs and Roma in the New Kosovo. Human Rights Watch, 11, 10 (D). Available at: www.hrw .org/reports/1999/kosov2/. Acessed 12/04/20.

Hylland Eriksen, T. 1993. Ethnicity and Nationalism: Anthropological Perspectives. London: Pluto Press.

Hymes, D. 1972. On communicative competence. In: Pride, J.B. and Holmes, J. (Eds), Sociolinguistics. Selected Readings. Harmondsworth: Penguin. Pp. 269-293.

Ilisei, I. 2012. Education of Roma women between feminism and multiculturalism study case: Roma women in Romania. JSSE-Journal of Social Science Education, 12(1), 67-75.

Iordanova, D. 2003. Images of Romanies in cinema: A rough sketch? Framework: The Journal of Cinema and Media, 44(2), 5-14.

Iordanova, D. 2008. Mimicry and plagiarism: Reconciling actual and metaphoric Gypsies. Third Text, 22(3), 305-310.

Irvine, J. \& Gal, S. 2000. Language ideology and linguistic differentiation. In: Kroskrity, P. V. (Ed.), Regimes of Language: Ideologies, Polities, and Identities. Santa Fe, NM: School of American Research Press. Pp. 35-84.

Jaffe, A. 1999. Ideologies in Action: Language Politics on Corsica. Berlin/New York: Walter de Gruyter.

Jaffe, A. 2003. Misrecognition unmasked? 'Polynomic' language, expert statuses and orthographic practices in Corsican schools. Pragmatics, 13(4), 515-539.

Jansen, S. 2005. Who's afraid of white socks? Towards a critical understanding of postYugoslav urban self-perceptions. Ethnologia Balkanica, 9, 151-167.

Jansen, S. 2008. Cosmopolitan openings and closures in post-Yugoslav antinationalism. In: Nowicka, M. \& Rovisco, M. (Eds.), Cosmopolitanism in Practice. Aldershot: Ashgate. Pp. 75-92.

Jansen, S. \& Löfving, S. 2008. Towards an anthropology of violence, hope, and the movement of people. In: Jansen, S. \& Löfving, S. (Eds.), Struggles for Home: Violence, Hope and the Movement of People. Oxford: Berghahn Books. Pp. 1-23.

Jansen, S. 2009. After the red passport: Towards an anthropology of the everyday geopolitics of entrapment in the EU's 'immediate outside'. Journal of the Royal Anthropological Institute, 15(4), 815-832.

Jašarević, L. 2007. Everyday work: Subsistence economy, social belonging and moralities of exchange at a Bosnian (black) market. In: Bougarel, X., Helms, E. \& Duijzings, G. (Eds.), The New Bosnian Mosaic: Identities, Memories and Moral Claims in a PostWar Society. Aldershot: Ashgate. Pp. 273-294.

Jeffrey, A. 2007. The geopolitical framing of localized struggles: NGOs in Bosnia and Herzegovina. Development and Change, 38(2), 251-274.

Jenkins, T. 1994. Fieldwork and the perception of everyday life. Man, 29(2), 433-455.

Jernudd, B. H. 1989. The texture of language purism: An introduction. In: Jernudd, B. H. $\&$ Shapiro, M. J. (Eds.), The Politics of Language Purism. Berlin/New York: Walter de Gruyter. Pp. 1-20. 


\section{Bibliography}

Jordan, B. 1989. Cosmopolitical obstetrics: Some insights from the training of traditional midwives. Social Science and Medicine, 28(9), 925-937.

Jovanović, J. \& Daroczi, A. C. 2015. Still missing intersectionality: The relevance of feminist methodologies in the struggle for the rights of Roma. Roma Rights Journal, 2, 79-82. Available at: www.errc.org/roma-rights-journal/roma-rights-2-2015-nothingabout-us-without-us-roma-participation-in-policy-making-and-knowledge-production /4433/12. . Accessed 12/04/20.

Jović, D. 2003. Yugoslavism and Yugoslav communism: From Tito to Kardelj. In: Djokić, D. (Ed.), Yugoslavism: Histories of a Failed Idea. Madison: The University of Wisconsin Press. Pp. 157-181.

Kalb, D. 2009. Conversations with a Polish populist: Tracing hidden histories of globalization, class, and dispossession in postsocialism (and beyond). American Ethnologist, 36(2), 207-223.

Kalb, D. 2014. Class. In: Nonini, D. (Ed.), A Companion to Urban Anthropology. Oxford: Blackwell. Pp. 157-176.

Kapralski, S. 1997. Identity building and the Holocaust: Roma political nationalism. Nationalities Papers, 25(2), 269-283.

Kent, S. A. 1997. Writing the Yugoslav Wars: English-language books on Bosnia (19921996) and the challenges of analyzing contemporary history. The American Historical Review, 102(4), 1085-1114.

Kibler, R. E. 2004. Responses to inhumanity in the Balkans and a preliminary discussion concerning the problem of evil. East European Quarterly, 38(4), 463-472.

Kiossev, A. 2002. The dark intimacy: Maps, identities, acts of identifications. In: Bjelić, D. I. \& Savić, O. (Eds.), Balkan as Metaphor: Between Globalization and Fragmentation. Cambridge, MA: MIT Press. Pp. 165-190.

Kirshenblatt-Gimblett, B. 2004. Intangible heritage as metacultural production. Museum International, 56(1-2), 52-65.

Kitromilides, P. M. 1989. 'Imagined Communities' and the origins of the national question in the Balkans. European History Quarterly, 19(2), 149-192.

Klumbyte, N. 2010. The Soviet sausage renaissance. American Anthropologist, 112(1), 22-37.

Kolstø, P. 2005. Myths \& Boundaries in South Eastern Europe. London: Hurst.

Kordić, S. 2010. Jezik i nacionalizam. Zagreb: Durieux.

Kostovicova, D. 2002. 'Shkolla shqipe' and nationhood: Albanians in pursuit of education in the native language in interwar (1918-41) and post-autonomy (1989-98) Kosovo. In: Schwandner-Sievers, S. \& Fischer, B. J. (Eds.) Albanian Identities: Myth and History. London: Hurst. Pp. 157-171.

Kovats, M. 2003. The politics of Roma identity: Between nationalism and destitution. Open Democracy, 29, 1-8.

Kraja, G. 2016. A symbol of repression which should remain just that. Kosovo Two Point Zero. Available at: http://kosovotwopointzero.com/en/a-symbol-of-repression-which -should-remain-just-that/. Accessed 12/04/20.

Krasniqi, G. 2015. Equal citizens, uneven communities: Differentiated and hierarchical citizenship in Kosovo. Ethnopolitics, 14(2), 197-217.

Kroskrity, P. V. 2000. Regimenting languages: Language ideological perspectives. In: Kroskrity, P. V. (Ed.), Regimes of Language: Ideologies, Polities, and Identities. Santa Fe, NM: School of American Research Press. Pp. 1-34.

Krstić, M. 2016. "I'm a poor lonesome cowboy and a long way from home...": Serbian documentary films about guest workers. Issues in Ethnology and Anthropology, 8(2), 499-518. 
Kruezi, S. 2008. Standardizumi Romani Qhib. Prizren: Berati.

Kruezi, S. 2014. O Roma \& i Romani Qhib. Krueziu (Self Published).

KTV (Kohavision). 2014. KTV lajme ROMET ne kosove mesojne SERBISHT. Available at: www.youtube.com/watch? $v=$ rwwGc64iE3E. Accessed 12/04/20.

Kuutma, K. 2009. Cultural heritage: An introduction to entanglements of knowledge, politics and property. Journal of Ethnology and Folkloristics, 3(2), 5-12.

Kyuchukov, H. 2011. Roma girls: Between traditional values and educational aspirations. Intercultural Education, 22(1), 97-104.

Labov, W. 2006 [1966]. The Social Stratification of English in New York. Cambridge: Cambridge University Press.

Ladányi, J. \& Szelényi, I. 2003. Historical variations in inter-ethnic relations: Toward a social history of Roma in Csenyéte, 1857-2000. Romani Studies, 13(1), 1-51.

Lampe, J. R. 2000. Yugoslavia as History: Twice There Was a Country. 2nd edition. Cambridge: Cambridge University Press.

Lampe, J. R. 2003. The two Yugoslavias as economic unions: Promise and problems. In: Djokić, D. (Ed.), Yugoslavism: Histories of a Failed Idea. Madison: The University of Wisconsin Press. Pp. 182-195.

Lave, J. 1982. A comparative approach to educational forms and learning processes. Anthropology and Education Quarterly, 13(2), 181-187.

le Normand, B. 2016. The gastarbajteri as a transnational Yugoslav working class. In: Archer, R., Duda, I. \& Stubbs, P. (Eds.), Social Inequalities and Discontent in Yugoslav Socialism. London/New York: Routledge. Pp. 38-57.

Leggio, D. V. 2011. Cosmopolitan virtual spaces: The Romani case. RomIdent Working Papers. Available at: http://romani.humanities.manchester.ac.uk/virtuallibrary/publicat ions.html. Accessed 12/04/20.

Leggio, D. V. 2013. Lace Avilen Ko Radio: Romani Language and Identity on the Internet. Unpublished Doctoral thesis. Manchester: University of Manchester.

Leggio, D. V. \& Matras, Y. 2013. Social networks as centres of language codification: Romani on YouTube. RomIdent Working Papers. Available at: http://romani.humani ties.manchester.ac.uk/virtuallibrary/publications.html.

Lemon, A. 2000. Between Two Fires: Gypsy Performance and Romani Memory from Pushkin to Postsocialism. Durham/London: Duke University Press.

Lichnofsky, C. 2013. Ashkali and Egyptians in Kosovo: New ethnic identifications as a result of exclusion during nationalist violence from 1990 till 2010. Romani Studies, 23(1), 29-60.

Macarie, I. C. 2014. Half-in, half-out: Roma and non-Roma Romanians with limited rights working and travelling in the European Union. Integrim Online Papers. Available at: www.i ntegrim.eu/wp-content/uploads/2014/02/Macarie-half-in-half-out.pdf. Accessed 12/04/20.

Maček, I. 2007. Imitation of life: Negotiating normality in Sarajevo under siege. In: Bougarel, X., Helms, E. \& Duijzings, G. (Eds.), The New Bosnian Mosaic: Identities, Memories and Moral Claims in a Post-War Society. Manchester: Ashgate Publishing Ltd.

Malcolm, N. 2002. Kosovo: A Short History. 2nd edition. London: Pan Books.

Marchand, T. 2007. Crafting knowledge: The role of 'parsing and production' in the communication of skill-based knowledge among masons. In: Harris, M. (Ed.), Ways of Knowing. New Approaches in the Anthropology of Experience and Learning. New York/Oxford: Berghahn Books. Pp. 181-202.

Marmullaku, R. 1975. Albanian and the Albanians. London: Hurst.

Marmullaku, R. 2003. Albanians in Yugoslavia: A personal essay. In: Djokić, D. (Ed.), Yugoslavism: Histories of a Failed Idea. Madison: The University of Wisconsin Press. Pp. 304-316. 
Marushiakova, E. \& Popov, V. 2001. New ethnic identities in the Balkans: The case of the Egyptians. Facta Universitatis-Series: Philosophy and Sociology, 2(8), 465-477.

Matras, Y. 1998a. Utterance modifiers and universals of grammatical borrowing. Linguistics, 36-2(2), 281-331.

Matras, Y. 1998b. Convergent development, grammaticalization, and the problem of 'mutual isomorphism'. In: Boeder, W., Schroeder, C., Wagner, K. H. \& Wildgen, W. (Eds.), Sprache in Raum und Zeit: Beiträge zur empirischen Sprachwissenschaft. Tübingen: Gunter Narr Verlag. Pp. 89-103.

Matras, Y. 1999. Writing Romani: The pragmatics of codification in a stateless language. Applied Linguistics, 20(4), 481-502.

Matras, Y. 2000. Fusion and the cognitive basis for bilingual discourse markers. International Journal of Bilingualism, 4(4), 505-528.

Matras, Y. \& Elšik, V. 2001. Romani Dialectological Questionnaire. Manchester: University of Manchester.

Matras, Y. 2002. Romani Linguistics. Cambridge: Cambridge University Press.

Matras, Y. \& Bakker, P. 2003. The study of mixed languages. In: Matras, Y. \& Bakker, P. (Eds.), The Mixed Language Debate: Theoretical and Empirical Advances. Berlin/New York: Walter de Gruyter. Pp. 1-20.

Matras, Y. 2004. Layers of convergent syntax in Macedonian Turkish. Mediterranean Language Review, 15, 63-86.

Matras, Y. \& Tufan, Ş. 2007. Grammatical borrowing in Macedonian Turkish. In: Matras, Y. \& Sakel, J. (Eds.), Grammatical Borrowing in Cross-Linguistic Perspective (Vol. 38). Berlin/New York: Walter de Gruyter. Pp. 215-227.

Matras, Y. 2009. Language Contact. Cambridge: Cambridge University Press.

Matras, Y. 2011. Universals of structural borrowing. In: Siemund, P. (Ed.), Linguistic Universals and Language Variation. Berlin: Walter de Gruyter. Pp. 204-235.

Matras, Y. 2013. Scholarship and the politics of Romani identity: Strategic and conceptual issues. European Yearbook of Minority Issues Online, 10(1), 209-247.

Matras, Y. 2014. I Met Lucky People: The Story of the Romani Gypsies. London: Allen Lane.

Mazower, M. 1995. The cold war and the appropriation of memory: Greece after liberation. East European Politics and Societies, 9(2), 272-294.

Mazower, M. 2000. A Short History of the Balkans. New York: Modern Library.

McClure, E. \& McClure, M. 1988. Macro-and micro-sociolinguistic dimensions of codeswitching in Vingard. In: Heller, M. (Ed.), Codeswitching: Anthropological and Sociolinguistic Perspectives. Berlin/New York/Amsterdam: Mouton de Gruyter. Pp. 25-51.

Megoran, N. 2013. Shared space, divided space: Narrating ethnic histories of Osh. Environment and Planning A, 45(4), 892-907.

Mehan, H. \& Griffin, P. 1980. Socialization: The view from classroom interactions. Sociological Inquiry, 50(3-4), 357-392.

Memorandum of the European Roma Rights Centre. 2005. In the aftermath of ethnic cleansing: Continued persecution of Roma, Ashkalis, Egyptians and others perceived as "Gypsies" in Kosovo: June 27, 2005. Available at: www.errc.org/article/in-the-afterma th-of-ethnic-cleansing-continued-persecution-of-roma-ashkalis-egyptians-and-others -perceived-as/2460. Accessed 12/04/20.

Menekshe, N. 2004. 35 Bersha e romano K.A.M. "Durmish Aslano" 1969-2004. Self-published.

Menekshe, N. 2009. Yubileyi 40 Bersh e KAM “Durmish Aslano" ano Prizren 1969 2009. Self-published.

Messerschmidt, D. A. 1981. Anthropologists at Home in North America: Methods and Issues in the Study of One's Own Society. Cambridge: Cambridge University Press. 
Mikuš, M. 2011. State pride Politics of LGBT Rights and Democratisation in European Serbia. East European Politics and Societies, 25(4), 834-851.

Mikuš, M. 2013. 'European Serbia' and its 'civil' discontents: Beyond liberal narratives of modernisation. Working Papers Series (Centre for Southeast European Studies) 7. Graz: Centre for Southeast European Studies. Available at: https://pure.mpg.de/pubma n/faces/ViewItemFullPage.jsp?itemId=item_2260567. Accessed 01/02/17.

Mikuš, M. 2015. Indigenizing "civil society" in Serbia what local fund-raising reveals about class and trust. Focaal, 2015(71), 43-56.

Milroy, J. 2001. Language ideologies and the consequences of standardization. Journal of Sociolinguistics, 5(4), 530-555.

Minks, A. 2010. Socializing heteroglossia among Miskitu children on the Caribbean coast of Nicaragua. Pragmatics, 20(4), 495-522.

Misha, P. 2002. Invention of a nationalism: Myth and amnesia. In: Schwandner-Sievers, S. \& Fischer, B. J. (Eds.), Albanian Identities: Myth and History. London: Hurst. Pp. 33-48.

Misini, A. 2014a. Drama - O Roma thay Ashkalie. Available at: www.youtube.com/watch

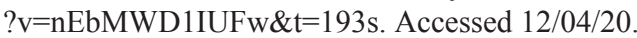

Misini, A. 2014b. Radio Prishtina - KAM Durmish Aslano 1972. Available at: www .youtube.com/watch?v=RYdBKHLsCRc. Accessed 12/04/20.

Mladenova, R. 2016. The figure of the imaginary gypsy in film: I even met happy Gypsies (1967). Romani Studies, 26(1), 1-30.

Moore, L. C. 2004. Second language acquisition and use in the Mandara Mountains. In: Echu, G. \& Gyasi Obeng, S. (Eds.), Africa Meets Europe: Language Contact in West Africa. New York: Nova Science. Pp. 131-148.

Moore, L. C. 2009. On communicative competence... in the field. Language and Communication, 29(3), 244-253.

Moyer, M. G. 2012. Sociolinguistic perspectives on language and multilingualism in institutions. In: Gardner, S. \& Martin-Jones, M. (Eds.), Multilingualism, Discourse, and Ethnography. London: Routledge. Pp.34-46.

Mueller, J. 2000. The banality of "ethnic war". International Security, 25(1), 42-70.

Myers-Scotton, C. 1988. Codeswitching as indexical of social negotiations. In: Heller, M. (Ed.), Codeswitching: Anthropological and Sociolinguistic Perspectives. Berlin/New York/Amsterdam: Mouton de Gruyter. Pp. 151-186.

Myers-Scotton, C. \& Bolonyai, A. 2001. Calculating speakers: Codeswitching in a rational choice model. Language in Society, 30(1), 1-28.

Naimark, N. \& Case, H. (Eds.). 2003. Yugoslavia and Its Historians: Understanding the Balkan Wars of the 1990s. Palo Alto: Stanford University Press.

Niedermüller, P. 1998. History, past, and the post-socialist nation. Ethnologia Europaea, 28(2), 169-182.

O'Keeffe, B. 2013. New Soviet Gypsies: Nationality, Performance, and Selfhood in the Early Soviet Union. Toronto: University of Toronto Press.

Olwig, K. F. \& Hastrup, K. 1997. Introduction. In: Olwig, K. F. \& Hastrup, K. (Eds.), Siting Culture: The Shifting Anthropological Object. London: Routledge. Pp. 1-15.

Oprea, A. 2004. Re-envisioning social justice from the ground up: Including the experiences of Romani women. Essex Human Rights Review, 1(1), 29-39.

Oprea, A. 2005. The arranged marriage of Ana Maria Cioaba, intra-community oppression and Romani feminist ideals transcending the 'primitive culture' argument. European Journal of Women's Studies, 12(2), 133-148.

Ortner, S. B. 1972. Is female to male as nature is to culture? Feminist Studies, 1(2), 5-31.

OSCE. 2015. Prizren municipal profile. Available at: www.osce.org/kosovo/13128 ?download=true. Accessed 12/04/20. 
Paugh, A. L. 2012. Playing with Languages: Children and Change in a Caribbean Village. New York/Oxford: Berghahn Books.

Pelissier, C. 1991. The anthropology of teaching and learning. Annual Review of Anthropology, 20(1), 75-95.

Perić, T. \& Demirovski, M. 2000. Unwanted: The exodus of Kosovo Roma (1998-2000). Cambridge Review of International Affairs, 13(2), 83-96.

Pétric, B. M. 2005. Post-Soviet Kyrgyzstan or the birth of a globalized protectorate. Central Asian Survey, 24(3), 319-332.

Petrova, D. 2003. The Roma: Between a myth and the future. Social Research, 70(1), 111-161.

Petrović, T. 2003. Studying the minority groups' identities in the Balkans from the perspective of language ideology. Balcanica, 34(34), 173-188.

Petrović, T. 2007. The territory of the former Yugoslavia in the "mental maps" of former Yugoslavs: Nostalgia for space. Sprawy Narodowościowe, 31, 263-273.

Petrović, T. 2008. Serbs, Albanians, and those in between: The gradation of otherness and identity management in the nation-building process. Two Homelands, 27, 67-81.

Petrović, T. 2010. "When we were Europe": Socialist workers in Serbia and their nostalgic narratives. The Case of the Cable Factory Workers in Jagodina. In: Todorova, M. (Ed.), Remembering Communism: Genres of Representation. New York: Social Science Research Council. Pp. 127-153.

Petrović, T. 2013. European new colonialism. Belgrade Journal of Media and Communications, 2(4), 111-128.

Phipps, A. 2010. Ethnographers as language learners: From oblivion and towards an echo. In: Collins, P. \& Gallinat, A. (Eds.), The Ethnographic Self as Resource: Writing Memory and Experience into Ethnography. New York/Oxford: Berghahn Books. Pp. 97-110.

Pine, F. 2002. Retreat to the household? In: Hann, C. M. (Ed.) 2002. Postsocialism: Ideals, Ideologies, and Practices in Eurasia. London: Routledge. Pp. 95-113.

Poplack, S. 1980. Sometimes I'll start a sentence in Spanish Y TERMINO en ESPANOL: Towards a typology of codeswitching. Linguistics, 18, 581-618.

Poulton, H. 2003. Macedonians and Albanians as Yugoslavs. In: Djokić, D. (Ed.), Yugoslavism: Histories of a Failed Idea. Madison: The University of Wisconsin Press. Pp. 115-134.

Pratt, M. L. 1991. Arts of the contact zone. Profession, 1, 33-40.

Rampton, B. 1995. Crossings: Language and Ethnicity among Adolescents. New York: Longman Group Limited.

Razsa, M. \& Lindstrom, N. 2004. Balkan is beautiful: Balkanism in the political discourse of Tudman's Croatia. East European Politics and Societies, 18(4), 628-650.

Reeves, M. 2005. Locating danger: Konfliktologiia and the search for fixity in the Ferghana Valley borderlands. Central Asian Survey, 24(1), 67-81.

Roberts, C. 1997. The year abroad as an ethnographic experience. In: Byram, M. (Ed.), Face to Face: Learning 'Language-and-Culture' Through Visits and Exchanges. London: Centre for Information on Language Teaching and Research (CILT). Pp. 62-76.

Romaine, S. 1994. Hawai'i Creole English as a literary language. Language in Society, 23(04), 527-554.

Said, E. 1978. Orientalism. New York: Pantheon Books.

Salvadori, E. 1997. Taking language beyond the classroom. In: Byram, M. (Ed.), Face to Face: Learning 'Language-and-Culture' Through Visits and Exchanges. London: Centre for Information on Language Teaching and Research (CILT). Pp. 18-35. 
Sampson, S. 1996. The social life of projects: Importing civil society to Albania. In: Hann, C. \& Dunn, E. (Eds.), Civil Society: Rethinking Western Models. London: Routledge. Pp. $120-138$.

Sardelić, J. 2013. Romani minorities on the margins of post-Yugoslav citizenship regimes. CITSEE Working Paper No. 2013/31. Available at: papers.ssrn.com/sol3/papers.cfm ?abstract_id=2388859. Accessed 12/04/20.

Sardelić, J. 2016. Roma between ethnic group and an 'underclass' as portrayed through newspaper discourses in socialist Slovenia. In: Archer, R., Duda, I. \& Stubbs, P. (Eds.), Social Inequalities and Discontent in Yugoslav Socialism. London/New York: Routledge. Pp. 95-111.

Schieffelin, B. \& Ochs, E. 1986. Language socialization. Annual Review of Anthropology, 15(1), 163-191.

Schultz, D. L. 2012. Translating intersectionality theory into practice: A tale of RomaniGadže feminist alliance. Signs, 38(1), 37-43.

Schwartz, T. 1981. The acquisition of culture. Ethos, 9(1), 4-17.

Shatri, B. 2010. Arsimi shqip në Kosovë, 1990-1999: Shtëpitë shkolla: Sfidat, arritjet dhe aspiratat. Prishtina: Shtëpia Botuese "Libri Shkollor".

Siegel, J. 1995. How to get a laugh in Fijian: Code-switching and humor. Language in Society, 24(1), 95-95.

Sigona, N. 2003. How can a nomad be a refugee? Kosovo Roma and labelling policy in Italy. Sociology, 37(1), 69-79.

Sigona, N. 2012. Between competing imaginaries of statehood. Roma: Ashkali and Egyptian (RAE) leadership in newly independent Kosovo. Journal of Ethnic and Migration Studies, 38(8), 1213-1232.

Silverman, C. 2011. Gypsy music, hybridity and appropriation: Balkan dilemmas of postmodernity. Ethnologia Balkanica, 15, 15-32.

Silverman, C. 2015. DJs and the production of "gypsy" music. Western Folklore, 74(1), $5-29$.

Silverstein, M. 1996. Monoglot "Standard" in America: Standardization and metaphors of linguistic hegemony. In: Brenneis, D. \& Macauley, R. (Eds.), The Matrix of Language: Contemporary Linguistic Anthropology. Boulder: Westview Press. Pp. 284-306.

Sorabji, C. 1995. A very modern war: Terror and territory in Bosnia-Hercegovina. In: Hinde, R. A. \& Watson, H. (Eds.), War: A Cruel Necessity?: The Bases of Institutionalized Violence. New York: IB Tauris. Pp. 80-98.

Sorabji, C. 2006. Managing memories in post-war Sarajevo: Individuals, bad memories, and new wars. Journal of the Royal Anthropological Institute, 12(1), 1-18.

Spasić, I. 2011. Cosmopolitanism as discourse and performance: A view from the semiperiphery. Revija za Sociologiju, 41(3), 269-290.

Spivak, G. C. 1988. Can the Subaltern Speak? Reflections on the History of an Idea. New York: Columbia University Press. Pp. 21-78.

Stefansson, A. 2007. Urban exile: Locals, newcomers and the cultural transformation of Sarajevo. In: Bougarel, X., Helms, E. \& Duijzings, G. (Eds.), The New Bosnian Mosaic: Identities, Memories and Moral Claims in a Post-War Society. Aldershot: Ashgate Publishing Ltd. : Pp. 59-78.

Stewart, M. 1999. "Brothers" and "orphans": Images of equality among Hungarian Rom. In: Day, S., Papataxiarchis, E. \& Stewart, M. (Eds.), Lilies of the Field. Boulder: Westview Press. Pp. 27-44. 
Stewart, M. 2002. Deprivation, the Roma and 'the Underclass'. In: Hann, C. M. (Ed.) 2002. Postsocialism: Ideals, Ideologies, and Practices in Eurasia. . London: Routledge. Pp. 133-155.

Stewart, M. 2004. Remembering without commemoration: The mnemonics and politics of Holocaust memories among European Roma. Journal of the Royal Anthropological Institute, 10(3), 561-582.

Stokes, G., Lampe, J., Rusinow, D. \& Mostov, J. 1996. Instant history: Understanding the Wars of Yugoslav Succession. Slavic Review, 55(1), 136-160.

Stolcke, V. 1994. Invaded women: Sex, race and class in the formation of colonial society. The European Journal of Development Research, 6(2), 7-21.

Ströhle, I. 2016. Of social inequalities in a socialist society: The creation of a rural underclass in Yugoslav Kosovo. In: Archer, R., Duda, I. \& Stubbs, P. (Eds.), Social Inequalities and Discontent in Yugoslav Socialism. London/New York: Routledge. Pp. 112-131.

Stubbs, P. 2002. Globalisation, memory and welfare regimes in transition: Towards an anthropology of transnational policy transfers. International Journal of Social Welfare, 11(4), 321-330.

Stubbs, P. 2009. Building capacity to promote social integration and social inclusion in the western Balkans. Paper Produced for Expert Group Meeting on Practical Strategies to Promote Social Integration: Lessons Learnt from Existing Policies and Practices. Accra, Ghana. Available at: www.un.org/esa/socdev/egms/docs/2009/Ghana/Stubbs. pdf. Accessed 12/04.20.

Stubbs, P. \& Maglajlić, R. A. 2012. Negotiating the transnational politics of social work in post-conflict and transition contexts: Reflections from South-East Europe. British Journal of Social Work, 42(6), 1-18.

Styan, J. L. 1968. The Dark Comedy: The Development of Modern Comic Tragedy. Cambridge: Cambridge University Press.

Sundar, N. 2004. Toward an anthropology of culpability. American Ethnologist, 31(2), $145-163$.

Sveriges Radio. 2014. Nevi ABC e romenge ani Kosova. Retrieved from sverigesradio.se/ sida/artikel.aspx?programid=2122\&artikel=5821074. Accessed 12/04/20.

Swaby, N. A. 2014. 'Disparate in voice, sympathetic in direction': Gendered political blackness and the politics of solidarity. Feminist Review, 108(1), 11-25.

Szeman, I. 2009. "Gypsy Music" and deejays: Orientalism, balkanism, and Romani musicians. TDR/the Drama Review, 53(3), 98-116.

Tanasković, D. 1991. The planning of Turkish as a minority language in Yugoslavia. In: Bugarski, R. \& Hawkesworth, C. (Eds.), Language Planning in Yugoslavia. Ohio: Slavica Publishers. Pp. 140-161.

Tarone, E. 2007. Sociolinguistic approaches to second language acquisition research1997-2007. The Modern Language Journal, 91(1), 837-848.

Temple, M. 1996. The politicization of history: Marshal Antonescu and Romania. East European Politics and Societies, 10(3), 457-503.

Thaçi, H. 2014. Kosovo is fully behind America's fight against Isis. The Guardian. Available at: www.theguardian.com/commentisfree/2014/sep/30/kosovo-america-isis -radicals-jihadi-networks. Accessed 12/04/20.

Thomas, G. 1978. The origin and nature of lexical purism in the Croatian variant of SerboCroatian. Canadian Slavonic Papers, 20(3), 405-420.

Thomas, G. 1988. Towards a typology of lexical purism in the Slavic literary languages. Canadian Slavonic Papers, 30(1), 96-111.

Thomas, G. 1991. Linguistic Purism. London: Longman Publishing Group. 
Tiefenbacher, B. 2013. Identifying "Roma" or constructing "the Other"? Slovak Romani men and women in processes of identification. European Yearbook of Minority Issues Online, 10(1), 249-268.

Todorova, M. 1994. The Balkans: From discovery to invention. Slavic Review, 53(2), 453-482.

Todorova, M. 1997. Imagining the Balkans. Oxford: Oxford University Press.

Todorova, M. 2015. Re-imagining the Balkans. In: Horvat, S. \& Štiks, I. (Eds.), Welcome to the Desert of Post-Socialism: Radical Politics After Yugoslavia. London: Verso. Pp. 85-102.

Tremlett, A. 2009. Comparing European institutional and Hungarian approaches to Roma (Gypsy) minorities. In: Agarin, T. \& Brosig, M. (eds.). Minority Integration: Debating Ethnic Diversity in Eastern Europe. Amsterdam: Rodopi. Pp. 129-150.

Trubeta, S. 2005. Balkan Egyptians and gypsy/Roma discourse. Nationalities Papers, 33(1), 71-95.

Tupas, R. 2014. Inequalities of Multilingualism: Challenges to mother-tongue based multilingual education. Language and Education, 29(2), 1-13.

UNESCO. 2015. What is intangible cultural heritage? Available at: unesco.org/culture/ich /index.php?pg=00002. Accessed 12/04/20.

Unkovski-Korica, V. 2015. Self-management, development and debt: The rise and fall of the 'Yugoslav experiment'. In: Horvat, S. \& Štiks, I. (Eds.), Welcome to the Desert of Post-Socialism: Radical Politics After Yugoslavia. London: Verso. Pp. 21-44.

Üsküp, Makedonya. 2014. Prizren agziyla.... Ah!-Nerde o esçi cünler.... Available at: www.youtube.com/watch?v=bOz2dMLjCns. Accessed 12/04/20.

van Baar, H. 2012. Socio-economic mobility and neo-liberal governmentality in postsocialist Europe: Activation and the dehumanisation of the Roma. Journal of Ethnic and Migration Studies, 38(8), 1289-1304.

van Boeschoten, R. 2000. The impossible return: Coping with separation and the reconstruction of memory in the wake of the civil war. In: Mazower, M. (Ed.), After the War Was Over: Reconstructing the Family, Nation and State in Greece, 1943-1960. Princeton: Princeton University Press. Pp. 122-140.

van de Port, M. 1998. Gypsies, Wars \& Other Instances of the Wild. Amsterdam: Amsterdam University Press.

Venkatesan, S. 2010. Learning to weave; weaving to learn... what? Journal of the Royal Anthropological Institute, 16(1), 158-175.

Verdery, K. 1991. National Ideology under Socialism: Identity and Cultural Politics in Ceausescu's Romania. Berkeley: University of California Press.

Verdery, K. 1993. Nationalism and national sentiment in post-socialist Romania. Slavic Review, 52(2), 179-203.

Verdery, K. 1996. Nationalism and national sentiment in postsocialist Romania. In: Verdery, K. (Ed.), What Was Socialism and What Comes Next. Princeton: Princeton University Press. Pp. 83-103.

Verdery, K. 2002. Whither postsocialism? In: Hann, C. M. (Ed.), Postsocialism: Ideals, Ideologies, and Practices in Eurasia. London: Routledge. Pp. 15-28.

Vermonden, D. 2013. Reproduction and development of expertise within communities of practice: A case study of fishing activities in South Buton. In: Heckler, S. (Ed.), Landscape, Process and Power: Re-Evaluating Traditional Environmental Knowledge. New York/Oxford: Berghahn Books. Pp. 205-229.

Vetta, T. 2009. 'Democracy Building' in Serbia: The NGO effect. Southeastern Europe, $33(1), 26-47$. 


\section{Bibliography}

Volčič, Z. 2005. The notion of 'the West' in the Serbian national imaginary. European Journal of Cultural Studies, 8(2), 155-175.

Voloshinov, V. N. 1973 [1929]. Marxism and the Philosophy of Language. Cambridge, MA/London: Harvard University Press.

Vygotsky, L. S. 1978. Mind in Society: The Development of Higher Psychological Processes. Cambridge, MA: Harvard University Press.

Wade, P. 2010. The presence and absence of race. Patterns of Prejudice, 44(1), 43-60.

Wade, P. 2012a. Race, kinship and the ambivalence of identity. In: Schramm, K., Skinner, D. \& Rottenburg, R. (Eds.), Identity Politics and the New Genetics: Re/Creating Categories of Difference and Belonging. New York/Oxford: Berghahn Books. Pp. 79-96.

Wade, P. 2012b. Skin colour and race as analytic concepts. Ethnic and Racial Studies, 35(7), 1169-1173.

Washabaugh, W. 1979. Linguistic anti-structure. Journal of Anthropological Research, 35(1), 30-46.

Wei, Li. 2012. Introduction to part 1. In: Gardner, S. \& Martin-Jones, M. (Eds.), Multilingualism, Discourse, and Ethnography. London: Routledge. Pp. 19-23.

Wexler, P. 1989. Hieratic components in soviet dictionaries of Yiddish, Dungan, and Belorussian. In: Jernudd, B. H. \& Shapiro, M. J. (Eds.), The Politics of Language Purism. Berlin, New York: Walter de Gruyter. Pp. 141-168.

Williams, B. 1987. Humor, linguistic ambiguity, and disputing in a Guyanese community. International Journal of the Sociology of Language, 65(65), 79-94.

Wilson, D. 1970. The Life and Times of Vuk St. Karadžić, 1787-1864; Literacy, Literature and National Independence in Serbia. Oxford: Clarendon Press.

Winnifrith, T. 1992. The Vlachs of the Balkans: A rural minority which never achieved ethnic identity. In: Howell, D. (Ed.), Roots of Rural Ethnic Mobilisation: Comparative Studies on Governments and Non-Dominant Ethnic Groups in Europe, 1850-1940. New York/Dartmouth: European Science Foundation/New York University Press. Pp. 58-73.

Wolcott, H. 1982. The anthropology of learning. Anthropology and Education, 13(2), $83-108$.

Woodward, S. L. 1995. Socialist Unemployment: The Political Economy of Yugoslavia, 1945-1990. Princeton: Princeton University Press.

Woolard, K. A. 1985. Language variation and cultural hegemony: Toward an integration of sociolinguistic and social theory. American Ethnologist, 12(4), 738-748.

Woolard, K. A. 1988. Codeswitching and comedy in Catalonia. In: Heller, M. (Ed.), Codeswitching: Anthropological and Sociolinguistic Perspectives. Berlin/New York/ Amsterdam: Mouton de Gruyter. Pp. 53-76.

Woolard, K. A. 1998. Introduction: Language ideology as a field of inquiry. In: Schieffelin, B. B., Woolard, K. A. \& Kroskrity, P. V. (Eds.), Language Ideologies: Practice and Theory. Oxford: Oxford University Press. Pp. 3-50.

Yasamee, F. A. 1995. Nationality in the Balkans: The case of the Macedonians. In: Özdoğan, G. G. \& Saybaşıl1, K. (Eds.), Balkans: A Mirror of the New International Order. Istanbul: EREN Yayınc1l1k ve Kitap, c1l1k. Pp. 121-132.

Young, V. A. 2004. Your average nigga. College Composition and Communication, 55(4), 693-715.

Živković, A. 2015. From the market ... to the market: The debt economy after Yugoslavia. In: Horvat, S. \& Štiks, I. (Eds.), Welcome to the Desert of Post-Socialism: Radical Politics After Yugoslavia. London: Verso. Pp. 45-64.

Živković, M. 2000. Jelly, slush, and red mists: Poetics of amorphous substances in Serbian jeremiads of the 1990s. Anthropology and Humanism, 25(2), 168-182.

Zymberi, I. 1991. Albanian in Yugoslavia. In: Bugarski, R. \& Hawkesworth, C. (Eds.), Language Planning in Yugoslavia. Ohio: Slavica Publishers. Pp. 130-139. 